Article

\title{
Graphene Aerogels for In Situ Synthesis of Conductive Poly(para-phenylenediamine) Polymers, and Their Sensor Application
}

\author{
Sahin Demirci ${ }^{1}$, Mehmet Can ${ }^{1}$ and Nurettin Sahiner ${ }^{1,2,3, * \mathbb{D}}$ \\ 1 Department of Chemistry \& Nanoscience and Technology Research and Application Center, \\ Canakkale Onsekiz Mart University Terzioglu Campus, Canakkale 17100, Turkey; \\ sahindemirci@gmail.com (S.D.); mehmetcann20@gmail.com (M.C.) \\ 2 Department of Chemical and Biomolecular Engineering, University of South Florida, Tampa, FL 33620, USA \\ 3 Department of Ophthalmology, Morsani College of Medicine, University of South Florida, \\ 12901 Bruce B. Downs Blvd, MDC21, Tampa, FL 33612, USA \\ * Correspondence: sahiner71@gmail.com
}

Received: 30 May 2020; Accepted: 26 June 2020; Published: 27 June 2020

\begin{abstract}
In this study, macroporous graphene aerogels (GAs) were synthesized by chemical reduction of graphene oxide sheets and were used as a support material for in situ synthesis of conductive poly(para-phenylenediamine) ( $\mathrm{p}(\mathrm{p}-\mathrm{PDA}))$. The in situ synthesis of $\mathrm{p}(\mathrm{p}-\mathrm{PDA})$ in GA was carried out by using a simple oxidation polymerization technique. Moreover, the prepared conductive $\mathrm{p}(\mathrm{p}-\mathrm{PDA})$ polymers in the networks of GAs were doped with various types of acids such as hydrochloric acid $(\mathrm{HCl})$, nitric acid $\left(\mathrm{HNO}_{3}\right)$, sulfuric acid $\left(\mathrm{H}_{2} \mathrm{SO}_{4}\right)$, phosphoric acid $\left(\mathrm{H}_{3} \mathrm{PO}_{4}\right)$, respectively. The prepared GA and different acid-doped forms as GA/p(p-PDA) composites were characterized by FT-IR, TGA, and conductivity measurements. The observed FT-IR peaks at $1574 \mathrm{~cm}^{-1}$, and $1491 \mathrm{~cm}^{-1}$, for stretching deformations of quinone and benzene, respectively, confirmed the in situ synthesis of $\mathrm{P}\left(\mathrm{p}\right.$-PDA) polymers within GAs. The conductivity of GAs with $2.17 \times 10^{-4} \pm 3.15 \times 10^{-5} \mathrm{~S} \cdot \mathrm{cm}^{-1}$ has experienced an approximately 250 -fold increase to $5.16 \times 10^{-2} \pm 2.72 \times 10^{-3} \mathrm{~S} \cdot \mathrm{cm}^{-1}$ after in situ synthesis of $\mathrm{p}(\mathrm{p}-\mathrm{PDA})$ polymers and with $\mathrm{HCl}$ doping. Conductivity values for different types of acid-doped GA/p (p-PDA) composites were compared with the bare $p$ (p-PDA) and their undoped forms. Moreover, the changes in the conductivity of GA and GA/p(p-PDA) composites upon $\mathrm{CO}_{2}$ gas exposure were compared and their sensory potential in terms of response and sensitivity, along with reusability in $\mathrm{CO}_{2}$ detection, were evaluated.
\end{abstract}

Keywords: graphene oxide; graphene aerogel; poly(para-phenylenediamine); GA/conductive polymer composite; conductivity; sensor

\section{Introduction}

Over the past decades, carbon-based materials have been the focus of eminent interest in both scientific and industrial fields due to their captivating mechanical, electrical, thermal, and physicochemical properties, as well as their environmentally friendly nature and economically viable accessibility that has collectively led to the emergence of diverse structures including carbon nanotubes (CNTs), carbon dots, mesoporous carbon, and graphene and so on [1-4]. Particularly, amongst all these materials, graphene has come into great prominence owing to its distinct characteristics such as great thermal and electrical conductivity, high stiffness, elasticity, and unique hexagonal monoatomic lattice structure with the high theoretical surface area of $\sim 2630 \mathrm{~m}^{2} / \mathrm{g}$ in the pristine form [5-7]. Graphene-based materials have been widely implemented in various areas [6-8] including solar cells [9-11], anti-corrosion coatings [12], electrode materials [13,14], sensors [14,15], 
biosensors [16-18], biomedical devices [2,19-21], and microelectronics [22], e.g., light-emitting diodes [23,24], displays [25-27], batteries [28,29] and supercapacitors [30,31]. However, innate functionalities of pristine graphene are only partially inherited into their incorporated polymer composites, mainly because of isolation and aggregation tendencies of graphene sheets, and its chemical stability most likely due to strong $\pi-\pi$ interactions [5,32]. Chemically modified graphene forms such as graphene oxides (GOs) have been produced by decorating 2D graphene sheets with various oxygen-containing moieties such as epoxy, hydroxyl, and carboxylic acid groups to surpass aggregation behaviors of graphene sheets $[7,33]$. Several methods of $G O$ preparation such as Hummers, Staudenmaier, Hoffmann, and Brodie methods and some of their modified forms are the most established ones [7]. GOs possess a good aqueous dispersibility and are electrical insulators because of the spoilage of the $\mathrm{sp}^{2}$ hybridization. Preparation of reduced GOs (r-GOs) can be achieved to solve poor conductivity of GOs by treating them with different reducing agents such as hydroquinone, diazene $\left(\mathrm{N}_{2} \mathrm{H}_{2}\right)$, hydrazine $\left(\mathrm{N}_{2} \mathrm{H}_{4}\right)$, sodium borohydride $\left(\mathrm{NaBH}_{4}\right)$, sodium hydroxide $(\mathrm{NaOH})$, sodium sulfide $\left(\mathrm{Na}_{2} \mathrm{~S}\right)$, sodium bisulfate $\left(\mathrm{NaHSO}_{3}\right)$, ascorbic acid $\left(\mathrm{C}_{6} \mathrm{H}_{8} \mathrm{O}_{6}\right)$, and hydroiodic acid (HI) [34,35]. GOs have been reported in preparation for a variety of composite materials [36] such as metal composites [37], various polymers, hydrogels [38], and cryogels [39].

Aerogels are a specific type of 3D network with ultra-low-density and extreme surface areas, highly porous structure, and great mechanical elasticity, and have been exploited in numerous applications e.g., electronic devices, heat insulation, catalysis, waste management, sensor application, and so on [40]. 3D GO and rGO-based materials i.e., graphene aerogels (GAs) can integrate superior properties of graphene materials in continuous aerogel networks preventing aggregation and collapsing of graphene sheets. GAs are also sought in numerous applications including chemiluminescence detection of macromolecules [41], catalysis [42], electrode materials, energy storage, supercapacitor applications [43], and remediation of pollutants $[44,45]$ such as dyes, pesticides, herbicides, and pathogens. Composites of GAs can be prepared by which the desired properties of guest molecules along with GAs can be combined in a single physical entity. Various nanoarchitectures and polymers were generated in situ within GAs such as $\mathrm{CoFe}_{2} \mathrm{O}_{4}$ nanoclusters [46], $\mathrm{TiO}_{2}$ [47], and $\mathrm{Co}$ [48] nanocrystals, gold nanoparticles [49], $\mathrm{Fe}_{3} \mathrm{O}_{4}$ nanoparticles [50], and quantum dots [51], along with some polymers such as polydimethylsiloxane [52], poly(aniline), poly(pyrrole) [34,53], and so on.

In situ synthesis of conductive polymers within 3D templating networks is of significant importance as the low stability of such polymers in freely standing forms was surmounted by the supporting matrix [54]. Besides the extra protection and stability incorporated within the composites, such kinds of hybrid structures integrate the inherent functionalities of their constituents into unique interfaces and exhibit superior properties than their precursors. Synthesis of various conductive polymers within porous networks has been reported such as poly(aniline), poly(pyrrole), and poly(thiophene) $[55,56]$. In the present study, the exceptional conductivity of p(p-PDA) was fortified by the extraordinary properties of GAs (high surface area and high porosity, robust and flexible mechanical properties, and the extremely light weight of the aerogel structure, and so on $[57,58])$.

Studies reported for $\mathrm{CO}_{2}$ detection in the literature are generally based on nondispersive infrared [59], electrochemical [60], optic [61], capacitive [62], and work function-based [63] sensors. Additionally, chemical sensors have received great attention in the detection of $\mathrm{CO}_{2}$. They give perceptible signals through gas-sensitive layers as changes in their conductivity, by which the amount of decrease or increase in their resistance or changes in their capacitive properties with the change of dielectric constants can be tracked upon $\mathrm{CO}_{2}$ gas exposure [64,65]. Because of the features such as low energy consumption, low cost, and flexible and adaptable size, which can be used in electronic applications, chemical sensors can afford noteworthy potentials for $\mathrm{CO}_{2}$ detection in different environments [66].

In this study, GOs were synthesized from graphite flakes by the modified Hummer method and then used in the fabrication of 3D highly porous GAs upon chemical reduction of the prepared GOs by L-Ascorbic acid (L-AA) as reducing agent and freeze-drying processes. Thereafter, a conductive 
polymer poly(para-phenylenediamine) ( $\mathrm{p}(\mathrm{p}-\mathrm{PDA}))$ was in situ synthesized within the pores of the prepared GAs followed by doping with several acids such as hydrochloric acid $(\mathrm{HCl})$, nitric acid $\left(\mathrm{HNO}_{3}\right)$, sulfuric acid $\left(\mathrm{H}_{2} \mathrm{SO}_{4}\right)$, and phosphoric acid $\left(\mathrm{H}_{3} \mathrm{PO}_{4}\right)$. The prepared $\mathrm{GA} / \mathrm{p}(\mathrm{p}-\mathrm{PDA})$ composites were characterized by Fourier transform infrared (FT-IR) spectroscopy, and thermal gravimetric (TG) analysis. The influences of different acid dopants on the electrical conductivity of GA/p(p-PDA) composites were determined and their sensory potentials against $\mathrm{CO}_{2}$ gas were investigated at ambient pressures and temperatures.

\section{Materials and Methods}

\subsection{Materials}

Graphite flakes (average particle size of 7-10 $\mu \mathrm{m}, 99 \%$ purity, Alfa Aesar), sodium nitrate ( $\mathrm{NaNO}_{3}, 99.0 \%-100.5 \%$, Merck), sodium hydroxide ( $\mathrm{NaOH}, 98 \%-100.5 \%$, Sigma-Aldrich), potassium permanganate $\left(\mathrm{KMnO}_{4}, 99 \%\right)$, hydrogen peroxide $\left(\mathrm{H}_{2} \mathrm{O}_{2}, 30 \%\right.$, Merck), and sulfuric acid $\left(\mathrm{H}_{2} \mathrm{SO}_{4}\right.$, 95\%-97\%, Sigma-Aldrich) were used in the preparation of GOs. L-Ascorbic acid (L-AA, 99\%, Sigma Aldrich) was used for the reduction of GOs nanosheets in synthesis GAs. P-Phenylenediamine (p-PDA, $98 \%$, Sigma Aldrich) was used as a monomer for in situ synthesis of p(p-PDA) in the GA networks, and ammonium persulfate (APS, $98 \%$, Sigma Aldrich) was used as an initiator of oxidative p-PDA polymerization. Hydrochloric acid ( $\mathrm{HCl}, 36 \%-38 \%$, Sigma Aldrich), nitric acid $\left(\mathrm{HNO}_{3}, 65 \%\right.$, Sigma Aldrich), sulfuric acid $\left(\mathrm{H}_{2} \mathrm{SO}_{4}, 98 \%\right.$, Merck), and phosphoric acid $\left(\mathrm{H}_{3} \mathrm{PO}_{4}, 85 \%\right.$, Sigma Aldrich) were used in the doping of in situ synthesized p(p-PDA) within GAs.

\subsection{Synthesis of Graphene Aerogels}

Graphene aerogels (GAs) were prepared by chemical reduction of prepared GOs following the cited literature with some modifications [34,67]. Concisely, $3.0 \mathrm{~g}$ of prepared GOs were dispersed in $500 \mathrm{~mL}$ DDW, following the modified Hummers method [39,68], with a final gravimetric concentration of $6 \mathrm{mg} / \mathrm{mL}$. A quantity of $20 \mathrm{~mL}$ of this solution containing GO layers was transferred into graduated cylinders and subjected to sonication for $3 \mathrm{~h}$ at $30^{\circ} \mathrm{C}-50^{\circ} \mathrm{C}$. After the sonication, the reducing agent L-AA was added into GO solution at a 3:1 w/w (L-AA:GO) ratio and sonicated for 1 min more to dissolve added L-AA. Then, the mixture was incubated without stirring at $40^{\circ} \mathrm{C}$ for $24 \mathrm{~h}$. Following the formation of black colored 3D graphene aerogel networks, they were transferred into $2.0 \mathrm{~L}$ beakers for washing in excess of DDW by continuously changing and replenishing the water every $8 \mathrm{~h}$ for 10 days. In the final step after washing, macroporous GAs were obtained via displacement of its liquid content with air by freeze-drying, and the resultant GAs were placed in closed tubes for further usage.

\subsection{Synthesis of Conductive Poly(p-phenylenediamine) ( $p(p-P D A))$}

The synthesis of conductive poly(p-phenylenediamine) ( $\mathrm{p}(\mathrm{p}-\mathrm{PDA}))$ was carried out in accordance with the literature [69-72]. In short, $25 \mathrm{~mL} 0.5 \mathrm{M} \mathrm{p}$ (p-PDA) solutions were prepared in DDW. After that, $1 \mathrm{M} 25 \mathrm{~mL}$ acid solutions containing 0.5 M APS were separately prepared from various acids such as $\mathrm{HCl}, \mathrm{HNO}_{3}, \mathrm{H}_{2} \mathrm{SO}_{4}$, and $\mathrm{H}_{3} \mathrm{PO}_{4}$ and added drop by drop in separate $\mathrm{p}$ (p-PDA) solutions in an ice bath. Afterward, the prepared p(p-PDA) polymers were collected by centrifugation at 10,000 rpm for $10 \mathrm{~min}$ and washed twice with water and acetone, then dried by using a heat gun.

\subsection{In Situ Synthesis of Conductive $p(p-P D A)$ within $G A s$}

For in situ synthesis of conductive $\mathrm{p}(\mathrm{p}-\mathrm{PDA})$ polymers within GA networks, the earlier reports on $\mathrm{p}(\mathrm{p}-\mathrm{PDA})$ synthesis were followed with some modifications [69-72]. Accordingly, the GAs were placed into $0.5 \mathrm{M} 50 \mathrm{~mL}$ aqueous solutions of p-PDA and stirred for $1 \mathrm{~h}$ at $100 \mathrm{rpm}$ in dark for loading of p-PDA monomers into pores and pore walls of the GAs. After that, the p-PDA loaded GAs were placed into $50 \mathrm{~mL}$ of different acid solutions containing $0.5 \mathrm{M}$ APS and $1 \mathrm{M}$ of various acids including $\mathrm{HCl}$, $\mathrm{HNO}_{3}, \mathrm{H}_{2} \mathrm{SO}_{4}$, and $\mathrm{H}_{3} \mathrm{PO}_{4}$, then stirred for $30 \mathrm{~min}$ more at $100 \mathrm{rpm}$ for in situ oxidative polymerization 
of p-PDA. Various acid-doped GA/p(p-PDA) composites were washed once with water and ethanol then dried in an oven at $50{ }^{\circ} \mathrm{C}$.

\subsection{Characterization}

Morphological properties of GA-based conductive polymer composites were assessed by scanning electron microscopy (SEM, Hitachi, Regulus 8230) operating in a low vacuum mode at a $5 \mathrm{kV}$ accelerating voltage. For the imaging, GA-based samples were mounted on aluminum SEM stubs with the aid of sticky carbon tapes, and the surface of the specimens was coated with gold to a few nanometers of thickness by a sputter coater to prevent excess charge buildup on the surface of specimens, and then samples were analyzed with SEM.

Functional groups of GAs and various acid-doped GA/p(p-PDA) composites were ascertained by FT-IR analysis and spectral peaks of these materials were recorded in the range of $650-4000 \mathrm{~cm}^{-1}$ with a $4 \mathrm{~cm}^{-1}$ resolution employing attenuated total reflectance of the attached FT-IR spectrometer (Thermo, Nicolet-iS10).

Thermal stabilities of GAs and various acid-doped GA/p(p-PDA) composites were determined by a TG analyzer (TGA, SII TG/DTA 6300, Exstar) under continuous purging of nitrogen gas with $200 \mathrm{~mL} / \mathrm{min}$ flow and the heating rate of $10^{\circ} \mathrm{C} / \mathrm{min}$ up to $900^{\circ} \mathrm{C}$.

Electrical conductivities of GAs, and acid-doped GA/P(p-PDA) composites were measured at room temperature via a computer-controlled electrometer (Keithley 2400 Source-Meter).

\subsection{Conductivity Measurements}

Conductivity measurements of GAs and various acid-doped GA/p(p-PDA) composites with lengths of $1.24 \pm 0.45 \mathrm{~cm}$ were performed by attaching small pieces of conductive carbon tape $(\sim 3 \times 4 \mathrm{~mm})$ to the top and bottom of bare and composite GA samples to connect the electrodes, followed by applying the voltage up to $40 \mathrm{~V}$. The conductivity values were calculated from the slope of the current-voltage (I-V) response curves at the Ohmic (linear) region by using Equations (1) and (2);

$$
\begin{gathered}
\mathrm{V}=\mathrm{I} \times \mathrm{R} \\
\sigma=(1 / \mathrm{R}) \times(\mathrm{l} / \mathrm{A})
\end{gathered}
$$

where, ' $V$ ' is the voltage, ' $I$ ' is the current, ' $R$ ' is the bulk resistance, ' $\sigma$ ' is the conductivity, ' $1 / R$ ' is the resistivity, ' $\mathrm{l}$ ' is the thickness and ' $\mathrm{A}$ ' is the cross-sectional area of the sample.

\subsection{Sensor Application of $\mathrm{GA}$ Based Composites to $\mathrm{CO}_{2} \mathrm{Gas}$}

The potential sensor application of the prepared GA-based composites to $\mathrm{CO}_{2}$ gas was investigated by tracking the change in their conductivity upon $\mathrm{CO}_{2}$ exposure. For this purpose, $0.25 \mathrm{~g}$ of bare $\mathrm{p}(\mathrm{p}-\mathrm{PDA})$ polymers were pelleted under compression of 10 tons of pressure, and the resulting pellet was exposed to $\mathrm{CO}_{2}$ gas for $30 \mathrm{~min}$. The sensory potential of $\mathrm{GA} / \mathrm{p}(\mathrm{p}-\mathrm{PDA})$ composites were also evaluated by $30 \mathrm{~min}$ of $\mathrm{CO}_{2}$ gas exposure, which corresponded to $11,980 \mathrm{ppm} \mathrm{CO}_{2}$. The conductivity of $\mathrm{p}(\mathrm{p}-\mathrm{PDA}) \mathrm{s}$, and GA/p(p-PDA) composites, were determined by recording their current-voltage curves via an electrometer and subsequent calculation of conductivity values from Equations (1) and (2). The sensitivity studies of $\mathrm{HCl}$-doped $\mathrm{GA} / \mathrm{p}$ (p-PDA) composites were conducted by exposing them to $\mathrm{CO}_{2}$ gas for $0.5,1,5,10,20,30,45$, and $60 \mathrm{~min}$ with the flow rate of $200 \mathrm{~mL} / \mathrm{min}$.

Besides, reusability of the $\mathrm{GA} / \mathrm{p}(\mathrm{p}-\mathrm{PDA})-\mathrm{HCl}$ composites was also investigated. Briefly, the $\mathrm{HCl}$-doped composite GA samples were treated with $\mathrm{CO}_{2}$ gas for $30 \mathrm{~min}$, and the change in their conductivity was recorded. After that, the used $\left(\mathrm{CO}_{2}\right.$ exposed) $\mathrm{GA} / \mathrm{p}(\mathrm{p}-\mathrm{PDA})-\mathrm{HCl}$ composites were incubated at $60^{\circ} \mathrm{C}$ for $2 \mathrm{~h}$ for regeneration of their conductivity and recovered conductivities were noted. Following the incubation, the composites were retreated with $\mathrm{CO}_{2}$ gas for another $30 \mathrm{~min}$ and the same reuse-regeneration cycles were applied for a total of 5 cycles. 


\section{Results and Discussion}

\subsection{In Situ Synthesis and Characterization of $p(p-P D A)$ within GAs}

The schematic illustration describing the preparation of GA/p (p-PDA) composites was given in Figure 1. The loading of p-PDA monomer into 3D GA networks was governed by simple ionic interactions of partially positive $\mathrm{p}(\mathrm{p}-\mathrm{PDA})$ monomers due to their amine groups with the partially negatively charged functional moieties of reduced GO sheets as well as hydrophobic interactions in GA networks, which was followed by oxidative polymerization in the presence of APS and various acid dopants such as $\mathrm{HCl}, \mathrm{HNO}_{3}, \mathrm{H}_{2} \mathrm{SO}_{4}$, and $\mathrm{H}_{3} \mathrm{PO}_{4}$.

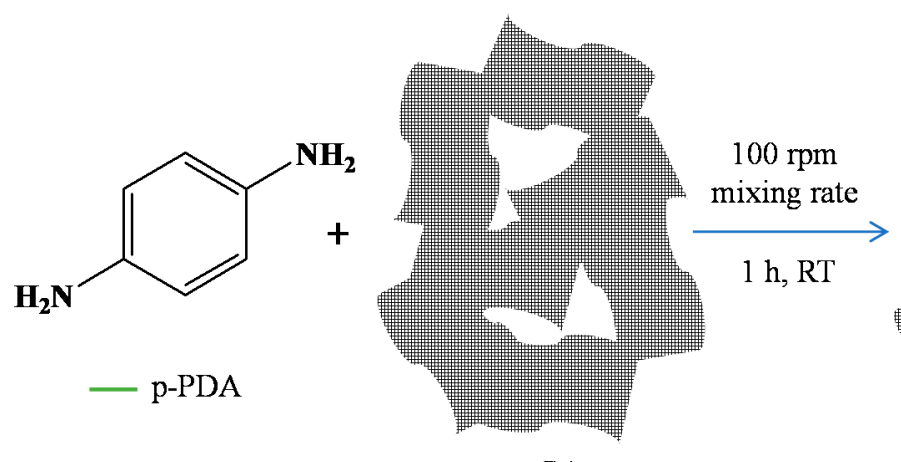

GA

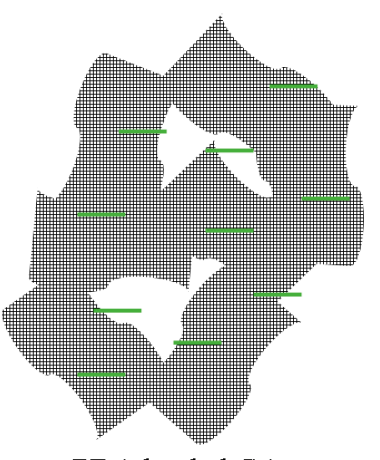

p-PDA loaded GA

APS solution in acid $\left(\mathrm{HCl}, \mathrm{HNO}_{3}, \mathrm{H}_{2} \mathrm{SO}_{4}\right.$, or $\left.\mathrm{H}_{3} \mathrm{PO}_{4}\right)$

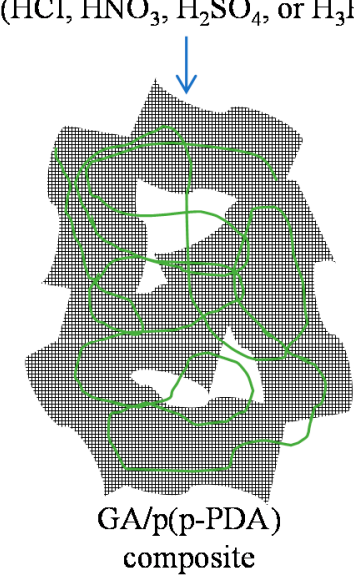
composite

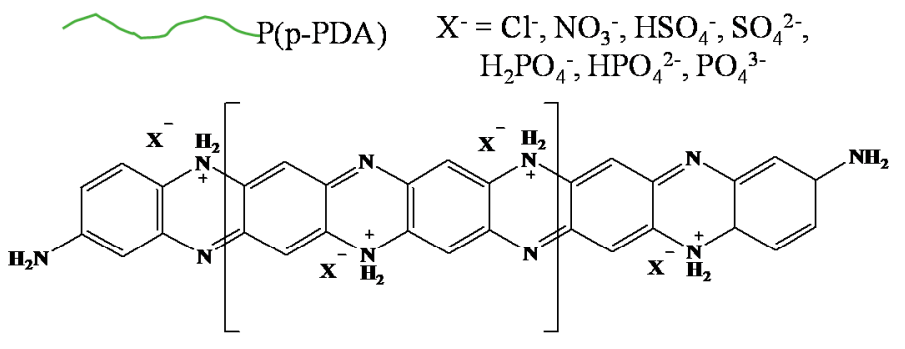
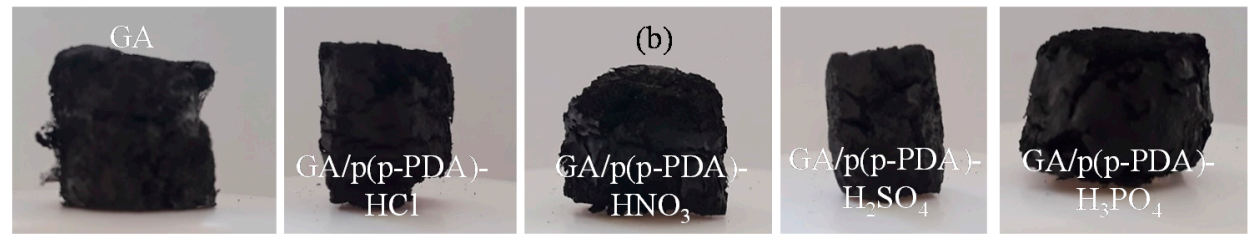

Figure 1. (a) Schematic illustration of GA/p(p-PDA) composite synthesis, and (b) digital camera images of $\mathrm{GA} / \mathrm{p}(\mathrm{p}-\mathrm{PDA})$ composites.

The amounts of in situ polymerized $\mathrm{p}(\mathrm{p}-\mathrm{PDA})$ within GA pieces were gravimetrically calculated by the mass difference between dried bare GA and GA/p(p-PDA) composites and the results are reported in Table 1. As can be clearly noticed wherefrom, for $1.0 \mathrm{~g}$ of GA, the highest amount of $\mathrm{p}$ (p-PDA) polymers were synthesized in the presence of $\mathrm{H}_{2} \mathrm{SO}_{4}$ acid doping as $3.94 \pm 0.8 \mathrm{~g} / \mathrm{g}$ of $\mathrm{GA}$. 
Table 1. The gravimetric amounts of in situ synthesized p(p-PDA) polymers within GAs.

\begin{tabular}{cccc}
\hline Type of Dopant & $\begin{array}{c}\text { GA } \\
\text { (g) }\end{array}$ & $\begin{array}{c}\text { GA/p(p-PDA) } \\
\text { (g) }\end{array}$ & $\begin{array}{c}\text { In Situ Synthesized } \\
\text { p(p-PDA) } \\
\text { (g/g) }\end{array}$ \\
\hline $\mathrm{HCl}$ & $0.04 \pm 0.002$ & $0.12 \pm 0.04$ & $2.08 \pm 0.5$ \\
$\mathrm{HNO}_{3}$ & $0.03 \pm 0.002$ & $0.08 \pm 0.01$ & $1.78 \pm 0.3$ \\
$\mathrm{H}_{2} \mathrm{SO}_{4}$ & $0.03 \pm 0.001$ & $0.15 \pm 0.03$ & $3.94 \pm 0.8$ \\
$\mathrm{H}_{3} \mathrm{PO}_{4}$ & $0.03 \pm 0.002$ & $0.14 \pm 0.04$ & $3.67 \pm 0.7$ \\
\hline
\end{tabular}

In the descending order $3.67 \pm 0.7 \mathrm{~g}, 2.08 \pm 0.5 \mathrm{~g}$, and $1.78 \pm 0.3 \mathrm{~g}$ of $\mathrm{p}(\mathrm{p}$-PDA) polymers were in situ synthesized by simultaneous doping of $\mathrm{H}_{3} \mathrm{PO}_{4}, \mathrm{HCl}$, and $\mathrm{HNO}_{3}$ acid solutions, respectively.

Moreover, the SEM analysis of GA-based composites revealed the existence of highly porous structures with pores of varying sizes, in a range of 1-100 $\mu \mathrm{m}$. The corresponding SEM images of GA, GA/p(p-PDA)-HCl, GA/p(p-PDA)-HNO $\mathrm{HN}_{3}, \mathrm{GA} / \mathrm{p}(\mathrm{p}-\mathrm{PDA})-\mathrm{H}_{2} \mathrm{SO}_{4}$, and GA/p(p-PDA)- $\mathrm{H}_{3} \mathrm{PO}_{4}$ composites are given in Figure 2a-e, respectively. As shown in the micrographs, the pores and pore walls of the GA composites were covered with the in situ synthesized conductive p(p-PDA)s. The least amount of $\mathrm{p}(\mathrm{p}-\mathrm{PDA})$ polymers appears to be the one that was synthesized in the presence of HNO3 acid doping with regards to other acid dopants.

It has been reported that high surface area, porosity, and pore volumes of GA-based materials favor diffusion of gases into the porous GA networks [73,74]. Thereby, these porous structures can be employed in various applications e.g., in situ synthesis of conductive polymers for potential sensor applications.

The FT-IR spectra of $\mathrm{p}(\mathrm{p}-\mathrm{PDA})$ and prepared bare $\mathrm{HCl}-, \mathrm{HNO}_{3}^{-}, \mathrm{H}_{2} \mathrm{SO}_{4^{-}}$, and $\mathrm{H}_{3} \mathrm{PO}_{4}$-doped conductive $\mathrm{p}(\mathrm{p}-\mathrm{PDA})$ polymers are given in Figure S1. The characteristic peaks of p-PDA at $3389 \mathrm{~cm}^{-1}$ was assigned to symmetric stretching vibrations of $=\mathrm{CH}$, and the peaks at $3032 \mathrm{~cm}^{-1}$ for symmetric and at 3302, and $3201 \mathrm{~cm}^{-1}$ were designated to asymmetric stretching vibrations of $\mathrm{N}-\mathrm{H}$ bonds. The spectral peaks observed at $1613 \mathrm{~cm}^{-1}$ were attributed to $\mathrm{N}-\mathrm{H}$ deformation of secondary amines, the peaks at $1502 \mathrm{~cm}^{-1}$ for symmetric stretching vibration of aromatic CC, the peaks at $1327 \mathrm{~cm}^{-1}$ for symmetric stretching of $\mathrm{C}-\mathrm{N}$, and the peaks that appeared at $807 \mathrm{~cm}^{-1}$ were assigned to out of plane deformation showing 1,4-distubistution in the benzene ring, respectively [75]. The FT-IR spectra of $p(p-P D A)$ polymers doped with various types of acids have shown the same characteristic peaks as stretching deformations of quinone at $1589 \mathrm{~cm}^{-1}$, stretching vibrations of benzene at $1503 \mathrm{~cm}^{-1}$, and also the peak at $1303 \mathrm{~cm}^{-1}$ can be assigned to C-N stretching in a secondary aromatic amine, 1098 and $1014 \mathrm{~cm}^{-1}$ for the aromatic C-H in-plane bending modes, and $807 \mathrm{~cm}^{-1}$ for out-of-plane deformations of $\mathrm{C}-\mathrm{H}$ in the 1,4-disubstituted benzene ring, respectively [76]. Moreover, the FT-IR spectrum of prepared GO, L-AA, $\mathrm{GA}$, and GA/Pp(p-PDA) composites by using various types of acids as doping agents were compared in Figure 3. 

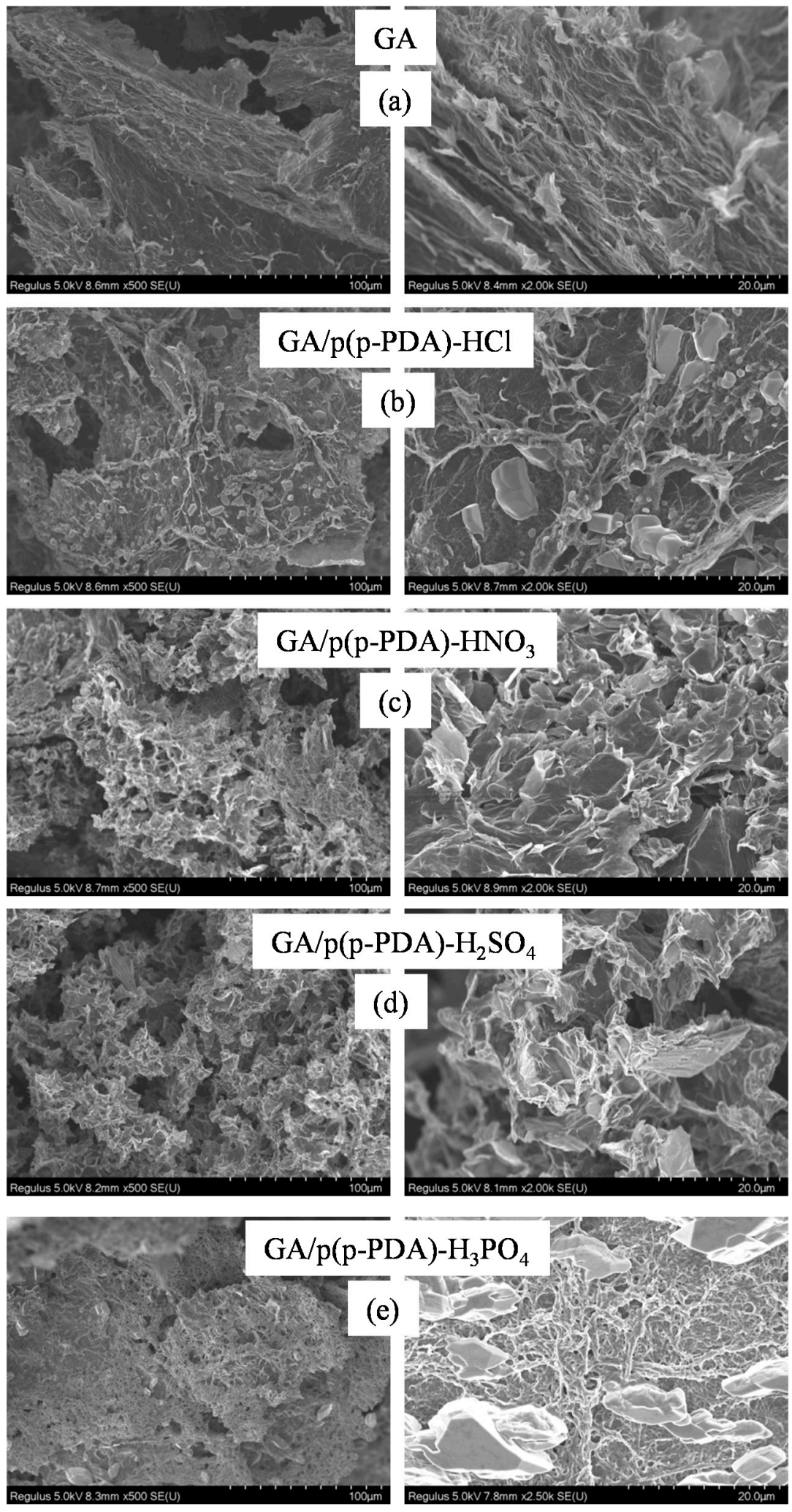

Figure 2. The SEM images of graphene aerogel (GA)-based composites; (a) GA, (b) GA/p(p-PDA)-HCl, (c) $\mathrm{GA} / \mathrm{p}(\mathrm{p}-\mathrm{PDA})-\mathrm{HNO}_{3}$, (d) GA/p(p-PDA)- $\mathrm{H}_{2} \mathrm{SO}_{4}$, and (e) GA/p(p-PDA)- $\mathrm{H}_{3} \mathrm{PO}_{4}$. 


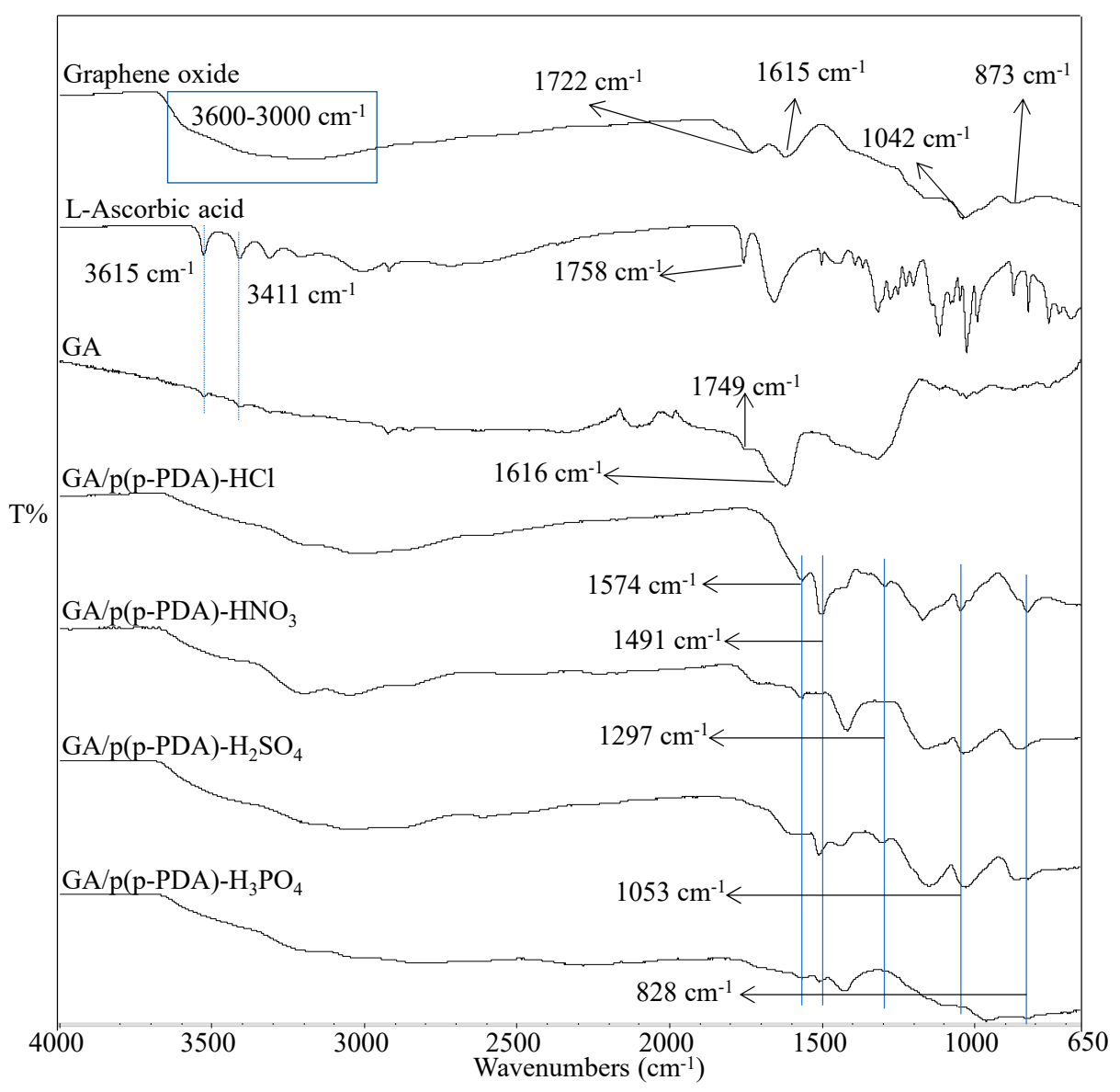

Figure 3. FT-IR spectra of GA/p(p-PDA) composites doped with various types of acids.

As it is readily seen from the FT-IR spectrum of GO, the O-H stretching vibrations were observed as $\mathrm{t}$ broad bands between $3600-3000 \mathrm{~cm}^{-1}$, and the peak for $\mathrm{C}=\mathrm{O}$ groups from both the carboxylic acid and ketones was observed at $1722 \mathrm{~cm}^{-1}[76,77]$. The peak at $1615 \mathrm{~cm}^{-1}$ was assigned to the aromatic $\mathrm{C}=\mathrm{C}$ bonds as a result of skeletal vibrations of unoxidized graphene units. The stretching vibrations at $1042 \mathrm{~cm}^{-1}$ and $873 \mathrm{~cm}^{-1}$, respectively, were attributed to C-O stretching modes of vibrations in the alkoxy and the ether groups of GO [77,78]. The FT-IR peaks that appeared at 3516, 3411, and $1645 \mathrm{~cm}^{-1}$ are assigned to $\mathrm{O}-\mathrm{H}$ groups, and the peak observed at $1758 \mathrm{~cm}^{-1}$ can further stem from the $\mathrm{C}=\mathrm{O}$ groups, which is noticeable from the FT-IR spectrum of L-AA [34]. For GA, the spectral peaks are seen at 3511 and $3408 \mathrm{~cm}^{-1}$ and are attributed to the $\mathrm{O}-\mathrm{H}$ stretching, and the peaks at $1749 \mathrm{~cm}^{-1}$ belong to $\mathrm{C}=\mathrm{O}$ stretching vibrations. The peaks that appeared at $1616 \mathrm{~cm}^{-1}$ can arise from the skeletal vibration of graphene sheets. From the oxidized graphene, GO sheets to their chemically reduced GA forms, the red shift can be readily noticed for $\mathrm{C}=\mathrm{O}$ bands with the respective change from 1722 to $1749 \mathrm{~cm}^{-1}$ [34]. Additionally, the characteristic peaks of $p(p-P D A)$, respectively, as stretching deformations of quinone at $1574 \mathrm{~cm}^{-1}$, stretching deformations of benzene at $1491 \mathrm{~cm}^{-1}$, and C-N stretching modes of a secondary aromatic amine at $1297 \mathrm{~cm}^{-1}$, aromatic C-H in-plane bending modes at $1053 \mathrm{~cm}^{-1}$, and the peaks at $828 \mathrm{~cm}^{-1}$ for out-of-plane deformations of C-H in the 1,4-disubstituted benzene ring can be realized from the given FT-IR spectra [76]. Based upon the systematical analyses of FT-IR spectra of the prepared GOs, GAs, and GA-p(p-PDA) composites, one can clearly state that the in situ syntheses of conductive $\mathrm{p}(\mathrm{p}-\mathrm{PDA})$ polymers were successfully achieved within 3D GAs.

The TGA thermograms of GA and various acid-doped GA/p(p-PDA) composites were compared in Figure 4. For GA, approximately $20 \%$ weight loss was observed at about $480{ }^{\circ} \mathrm{C}$, and cumulatively $75 \%$ of its weight was lost up to heating $580^{\circ} \mathrm{C}$, and from thereon, no significant weight loss was observed by heating up to $1000^{\circ} \mathrm{C}$. 


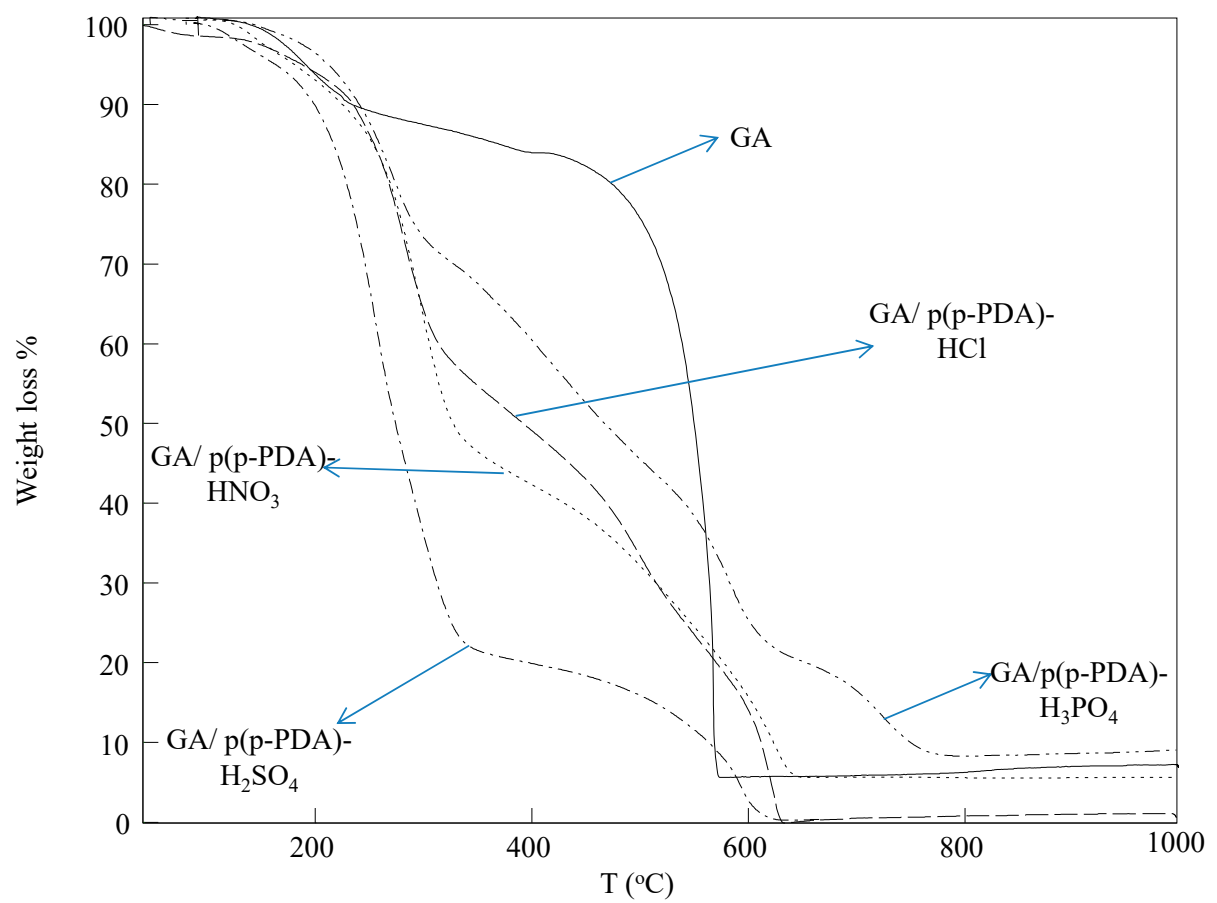

Figure 4. Thermal gravimetric (TG) thermograms of GA/p(p-PDA) composites doped with various types of acids.

All of the GA/p (p-PDA) composites shared similar decomposition patterns. The first thermal decomposition of $\mathrm{HCl}$-doped $\mathrm{GA} / \mathrm{p}$ (p-PDA) composites was recorded between $30-225^{\circ} \mathrm{C}$ with $8.4 \%$ weight loss, the second step was observed between $230-315^{\circ} \mathrm{C}$ with $39.9 \%$ cumulative weight loss, and the last step was occurred between $320-630^{\circ} \mathrm{C}$ with a final result of more than $99 \%$ cumulative weight loss. The $\mathrm{HNO}_{3}$-doped GA/p (p-PDA) composites were recorded to show $13.3 \%$ weight loss between $110-245^{\circ} \mathrm{C}$, the second and third steps of thermal decomposition occurred between $250-330{ }^{\circ} \mathrm{C}$, and $340-640^{\circ} \mathrm{C}$ with $50.1 \%$, and $93.9 \%$ cumulative weight losses, respectively. $\mathrm{H}_{2} \mathrm{SO}_{4}$-doped GA/p(p-PDA) composites showed approximately $7.5 \%$ weight loss up to $185^{\circ} \mathrm{C}$, and heating up to $340{ }^{\circ} \mathrm{C}$ resulted in a cumulative weight loss of $77.4 \%$. In addition, in the final decomposition step, more than $99 \%$ cumulative weight loss was observed by heating up to $630^{\circ} \mathrm{C}$. For the $\mathrm{H}_{3} \mathrm{PO}_{4}$-doped GA/p (p-PDA) composites, $24.3 \%$ weight loss was recorded between $130-290^{\circ} \mathrm{C}$. The second step occurred between 540-620 ${ }^{\circ} \mathrm{C}$ with $77.8 \%$ cumulative weight loss, and the last step of thermal decomposition was seen between $690-780{ }^{\circ} \mathrm{C}$ with a final cumulative weight loss of $91.5 \%$ (8.5\% remaining residues). Moreover, according to TGA data obtained, $\mathrm{H}_{2} \mathrm{SO}_{4}$-doped GA/p(p-PDA) composites were the least thermally stable composite, which was followed by $\mathrm{HCl}$-doped GA/p(p-PDA) composites. Comparatively, the $\mathrm{H}_{3} \mathrm{PO}_{4}$ - and $\mathrm{HNO}_{3}$-doped $\mathrm{GA} / \mathrm{p}(\mathrm{p}$-PDA) composites exhibited better thermal stability and higher remaining residues than the ones doped with $\mathrm{H}_{2} \mathrm{SO}_{4}$ and $\mathrm{HCl}$, while all of the composites show similar patterns of thermal degradation. The differences seen within thermal degradation profiles of the GA/p(p-PDA) composites can be attributed to the distinctive effects of various acids dopants on the structure and morphology of the in situ synthesized conductive polymers. Particularly, as can be noticeable from the SEM images provided in Figure 2, the crystal structure of the GA-based polymer composites shows dopant-dependent variations, as it was also stated elsewhere that in situ synthesized conductive polymers can exhibit differences in their size and crystal structures with the effects of different doping acids [79]. 


\subsection{Conductivity Measurements}

Carbon-based graphite, graphene oxide, graphene and/or graphene aerogels have three valence bands where electrons are in high attraction with the central nucleus. There is a free electron called $\pi$-electron that does not pass through the Fermi level as in the metals, however, the Fermi level has a narrow band that can easily shift the electron from the valance band to the conduction band and creates electron conductivity [80]. One of the most important properties of the conductivity of these carbon-based materials is that the in-plane electrical conductivity in their structure is much more than the out-of-plane electrical conductivity, mainly due to the low area between the graphitic layers, resulting from the weak $\pi$-electron bands connecting different layers of graphite [80,81]. On the other hand, in conductive polymers known as conjugated organic polymers, conductivity is associated with self-settling solitons, polarons, and bipolarons in the polymer chain [68,69]. These carriers become mobile in the electric field and move along the polymer chain, causing electrical conductivity. The I-V response plots of the various acid-doped $p(p-P D A)$ and GA/p (p-PDA) composites are given in Figure 5a,b.
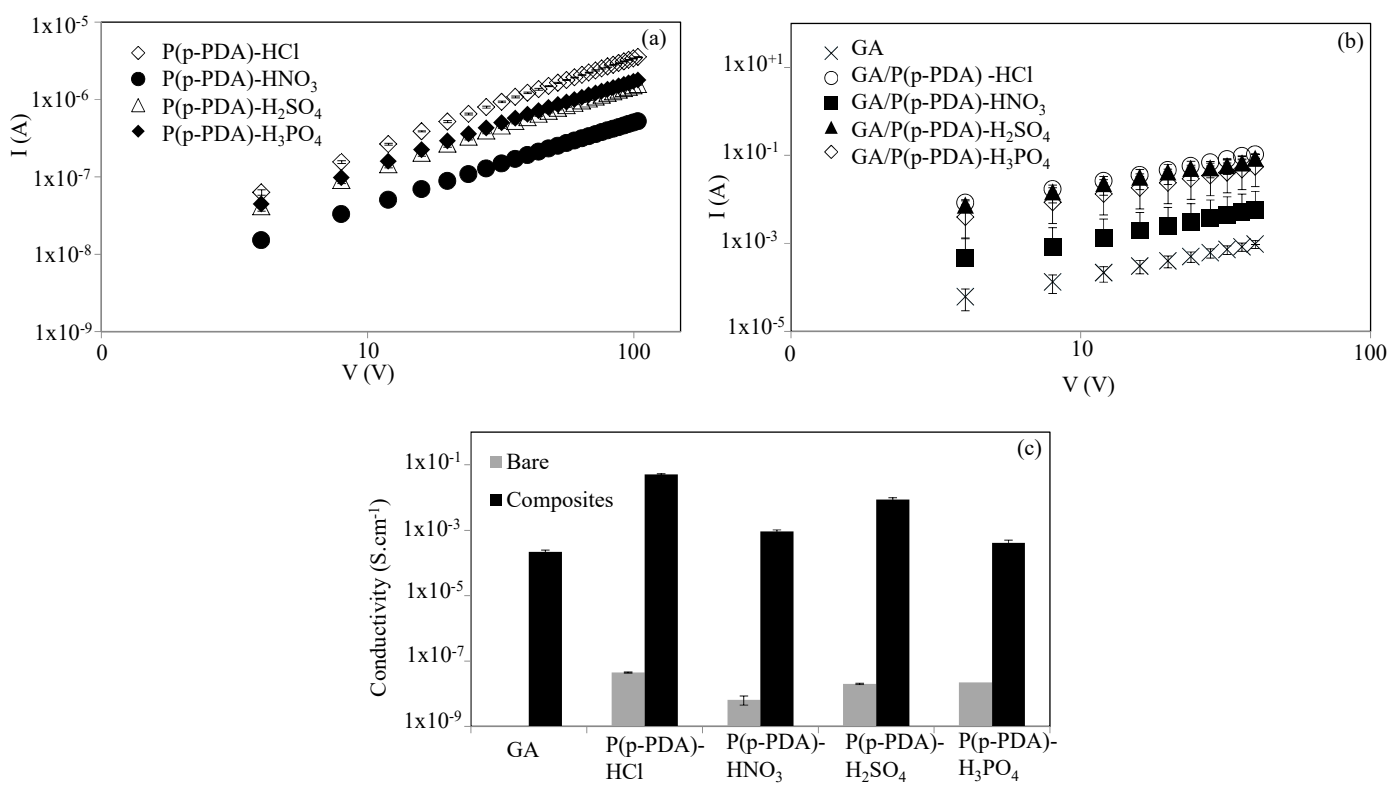

Figure 5. The current (I) versus voltage (V) plots of (a) $p(p-P D A)$ polymers, (b) GA/p (p-PDA) composites and (c) comparison of calculated conductivity values for $p(p-P D A)$ and GA/p(p-PDA) composites.

From these plots, the conductivity values for $\mathrm{p}(\mathrm{p}-\mathrm{PDA})$ polymers and GA/p (p-PDA) composites the were calculated using Equations (1) and (2), respectively, and compared in Figure 5c. It was observed that the conductivity of GAs increased with the in situ synthesis of p(p-PDA). Electrical conductivities of bare $p(p-P D A)$ and GA/p (p-PDA) composites were also given in Table 2. As given, the conductivities of $\mathrm{p}(\mathrm{p}-\mathrm{PDA})$ polymers different from each other depending on the type of acid dopant used. The conductivities of $\mathrm{p}(\mathrm{p}-\mathrm{PDA})-\mathrm{HCl}, \mathrm{p}(\mathrm{p}-\mathrm{PDA})-\mathrm{HNO}_{3}, \mathrm{p}(\mathrm{p}-\mathrm{PDA})-\mathrm{H}_{2} \mathrm{SO}_{4}$, and $\mathrm{p}(\mathrm{p}-\mathrm{PDA})-\mathrm{H}_{3} \mathrm{PO}_{4}$ were calculated as $4.46 \times 10^{-8} \pm 1.12 \times 10^{-8}, 6.46 \times 10^{-9} \pm 2.24 \times 10^{-9}, 1.99 \times 10^{-8} \pm 1.93 \times 10^{-9}$, and $2.22 \times 10^{-8} \pm 1.11 \times 10^{-9} \mathrm{~S} \cdot \mathrm{cm}^{-1}$, respectively. From these values, the highest conductivity was measured for the $\mathrm{HCl}$-doped $\mathrm{p}$ (p-PDA) polymers, which is approximately 7-fold greater than $\mathrm{HNO}_{3}$, and 2-fold higher than the conductivities of $\mathrm{H}_{2} \mathrm{SO}_{4}^{-}$, and $\mathrm{H}_{3} \mathrm{PO}_{4}$-doped $\mathrm{p}$ (p-PDA) polymers. Electrical conductivity of bare GAs was calculated as $2.17 \times 10^{-4} \pm 3.15 \times 10^{-5} \mathrm{~S} \cdot \mathrm{cm}^{-1}$, which is much higher than all types of $\mathrm{p}(\mathrm{p}-\mathrm{PDA})$ polymers with different acid doping. As was expected, conductivity of GAs underwent a significant rise after in situ preparation within GA of various acid-doped forms as $\mathrm{GA} / \mathrm{p}(\mathrm{p}-\mathrm{PDA})$ composites. 
Table 2. The change in conductivities of $\mathrm{p}(\mathrm{p}-\mathrm{PDA})$ polymers, and GA/p (p-PDA) composites upon 30 min of $\mathrm{CO}_{2}$ exposure.

\begin{tabular}{|c|c|c|c|}
\hline \multirow{3}{*}{ Type of Dopant } & \multicolumn{2}{|c|}{$\begin{array}{l}\text { Conductivity } \\
\left(\mathrm{S} \cdot \mathrm{cm}^{-1}\right)\end{array}$} & \multirow{3}{*}{$\begin{array}{l}\text { Decrease in Conductivity } \\
\text { (fold) }\end{array}$} \\
\hline & \multicolumn{2}{|c|}{$P(p-P D A)$} & \\
\hline & Before & After & \\
\hline $\mathrm{HCl}$ & $4.46 \times 10^{-8} \pm 1.12 \times 10^{-8}$ & $3.12 \times 10^{-9} \pm 7.54 \times 10^{-10}$ & $\sim 14$ \\
\hline $\mathrm{HNO}_{3}$ & $6.46 \times 10^{-9} \pm 2.24 \times 10^{-9}$ & $4.89 \times 10^{-10} \pm 3.89 \times 10^{-11}$ & $\sim 13$ \\
\hline $\mathrm{H}_{2} \mathrm{SO}_{4}$ & $1.99 \times 10^{-8} \pm 1.93 \times 10^{-9}$ & $1.11 \times 10^{-9} \pm 3.11 \times 10^{-10}$ & $\sim 18$ \\
\hline $\mathrm{H}_{3} \mathrm{PO}_{4}$ & $2.22 \times 10^{-8} \pm 1.11 \times 10^{-9}$ & $3.81 \times 10^{-9} \pm 5.99 \times 10^{-10}$ & $\sim 6$ \\
\hline \multirow{2}{*}{ Materials } & \multicolumn{2}{|c|}{ GA based composites } & Decrease in conductivity \\
\hline & Before & After & (fold) \\
\hline GA & $2.17 \times 10^{-4} \pm 3.15 \times 10^{-5}$ & $1.23 \times 10^{-4} \pm 2.11 \times 10^{-5}$ & $\sim 2$ \\
\hline GA/p(pPDA)-HCl & $5.16 \times 10^{-2} \pm 2.72 \times 10^{-3}$ & $8.52 \times 10^{-5} \pm 1.21 \times 10^{-5}$ & $\sim 600$ \\
\hline $\mathrm{GA} / \mathrm{p}(\mathrm{pPDA})-\mathrm{HNO}_{3}$ & $9.19 \times 10^{-4} \pm 1.29 \times 10^{-4}$ & $7.23 \times 10^{-5} \pm 9.88 \times 10^{-6}$ & $\sim 13$ \\
\hline $\mathrm{GA} / \mathrm{p}(\mathrm{pPDA})-\mathrm{H}_{2} \mathrm{SO}_{4}$ & $8.78 \times 10^{-3} \pm 1.17 \times 10^{-3}$ & $8.91 \times 10^{-5} \pm 1.19 \times 10^{-5}$ & $\sim 100$ \\
\hline $\mathrm{GA} / \mathrm{p}(\mathrm{pPDA})-\mathrm{H}_{3} \mathrm{PO}_{4}$ & $4.11 \times 10^{-4} \pm 9.13 \times 10^{-5}$ & $3.51 \times 10^{-5} \pm 6.33 \times 10^{-6}$ & $\sim 12$ \\
\hline
\end{tabular}

Conductivity of $\mathrm{HCl}-, \mathrm{HNO}_{3}-\mathrm{H}_{2} \mathrm{SO}_{4}^{-}$, and $\mathrm{H}_{3} \mathrm{PO}_{4}$-doped $\mathrm{GA} / \mathrm{p}(\mathrm{p}-\mathrm{PDA})$ composites were calculated to be $5.16 \times 10^{-2} \pm 2.72 \times 10^{-3} \mathrm{~S} \cdot \mathrm{cm}^{-1}, 9.19 \times 10^{-4} \pm 1.29 \times 10^{-4} \mathrm{~S} \cdot \mathrm{cm}^{-1}, 8.78 \times 10^{-3}$ $\pm 1.17 \times 10^{-3} \mathrm{~S} \cdot \mathrm{cm}^{-1}$, and $4.11 \times 10^{-4} \pm 9.13 \times 10^{-5} \mathrm{~S} \cdot \mathrm{cm}^{-1}$, respectively. These values were approximately 250-, 4-, 40-, and 2-fold greater than the conductivity of bare GAs, respectively. As it is in a good agreement with the conductivity of $\mathrm{HCl}$-doped bare $\mathrm{p}(\mathrm{p}-\mathrm{PDA})$ polymers, the conductivity of in situ prepared HCl-doped GA/p(p-PDA) composites with $5.16 \times 10^{-2} \pm 2.72 \times 10^{-3} \mathrm{~S}^{-\mathrm{cm}^{-1}}$ is approximately 60-fold, 6-fold, and 125-fold higher than those of $\mathrm{HNO}_{3}-, \mathrm{H}_{2} \mathrm{SO}_{4^{-}}$, and $\mathrm{H}_{3} \mathrm{PO}_{4}$-doped $\mathrm{GA} / \mathrm{P}$ (p-PDA) composites, respectively. Obviously, different types of acid dopants have imparted distinct conductivity values to the GA based composites. The higher conductivity was observed for in situ prepared $\mathrm{HCl}$-doped GA/p(p-PDA) composites. As mentioned earlier, in the literature, the types of the used acids for doping of conductive polymers have significant effects on size and crystal structure of the conductive polymers, and higher crystallinity was observed in $\mathrm{HCl}$-doped conductive polymers amongst doping of several others [79]. As it is clearly seen from Table 1 and SEM images of the GA-based composites, the amount of in situ prepared HCl-doped p(p-PDA) is more than the in situ prepared amounts within $\mathrm{HNO}_{3}$-doped p(p-PDA) GAs, so is its conductivity. Therewithal, the smaller size of $\mathrm{HCl}$ than other used acids can make it a better dopant as it can more readily diffuse into pores of GA composites. Therefore, the highest conductivity values were observed in in situ prepared $\mathrm{HCl}$-doped GA/p(p-PDA) composites.

\subsection{Conductivity Change of $\mathrm{GA}$ Based Composites in Response to $\mathrm{CO}_{2}$ Gas Exposure}

Carbon dioxide $\left(\mathrm{CO}_{2}\right)$ gas, as one of the most dangerous causatives of global warming, is increasing continuously in the atmosphere. According to the standards reported by the American Association of Heating, Refrigerating and Air Conditioning Engineers (ASHRAE), the concentration of $\mathrm{CO}_{2}$ required for healthy breathing should not exceed $1000 \mathrm{ppm}$ [82]. However, according to the results of extensive research and measurements, the amount of industrial $\mathrm{CO}_{2}$ emission is many times higher than this threshold. The $\mathrm{CO}_{2}$ concentration in the atmosphere increased from $414 \mathrm{ppm}$ in May 2019 to $417 \mathrm{ppm}$ in May 2020 [83]. It is urgent to take serious precautions to cope with this steady $\mathrm{CO}_{2}$ increase in the atmosphere. Therefore, the design and use of functional materials that can sense, capture, and store the ways in which the emission of pollutant gases, whose concentration in the atmosphere intensifies daily, endangers the lives of all living creatures. Therefore, $\mathrm{CO}_{2}$ sensors and adsorbent potentials of the prepared bare $\mathrm{p}(\mathrm{p}-\mathrm{PDA})$ polymers, GAs, and GA/p(p-PDA) composites were evaluated by exposing them to $\mathrm{CO}_{2}$ gas and the changes in their conductivity were examined. The experimental setup used in the $\mathrm{CO}_{2}$ exposure of prepared materials was reported in the literature [84]. The $\mathrm{HCl}-, \mathrm{HNO}_{3}-, \mathrm{H}_{2} \mathrm{SO}_{4}{ }^{-}$, and $\mathrm{H}_{3} \mathrm{PO}_{4}$-doped $\mathrm{p}$ (p-PDA) polymers and their GA composites of known conductivities were exposed 
to $\mathrm{CO}_{2}$ gas for $30 \mathrm{~min}$ at $100 \mathrm{~mL} / \mathrm{min}$ flow rate and the variations in their conductivities in response to $\mathrm{CO}_{2}$ gas exposure were illustrated in Figure $6 \mathrm{a}, \mathrm{b}$, respectively. It was clearly seen that the conductivity of various acid-doped $\mathrm{P}(\mathrm{p}-\mathrm{PDA})$ polymers and $\mathrm{GA} / \mathrm{P}(\mathrm{p}-\mathrm{PDA})$ composites decreased after $30 \mathrm{~min}$ of $\mathrm{CO}_{2}$ exposure. The extent of conductivity falls of these acid-doped P(p-PDA) polymers and GA/P(p-PDA) composites are given in Table 2 . As it was realized therefrom, an approximately 15 -fold decrease in the conductivity of $\mathrm{HCl}$-doped P(p-PDA) was observed from $4.46 \times 10^{-8} \pm 1.12 \times 10^{-8} \mathrm{~S} \cdot \mathrm{cm}^{-1}$ to 3.12 $\times 10^{-9} \pm 7.57 \times 10^{-10} \mathrm{~S} \cdot \mathrm{cm}^{-1}$ after $30 \mathrm{~min}$ of $\mathrm{CO}_{2}$ gas exposure. Similarly, $\mathrm{HNO}_{3}$ - and $\mathrm{H}_{2} \mathrm{SO}_{4}$-doped $\mathrm{P}(\mathrm{p}-\mathrm{PDA})$ polymers have experienced, respectively, about 13-, and 18-fold decrease after $30 \mathrm{~min}$ of $\mathrm{CO}_{2}$ gas exposure. On the other hand, the decrease in conductivity of $\mathrm{H}_{3} \mathrm{PO}_{4}$-doped $\mathrm{P}(\mathrm{p}-\mathrm{PDA})$ was slightly lower than that of the others with approximately 6-fold reduction.
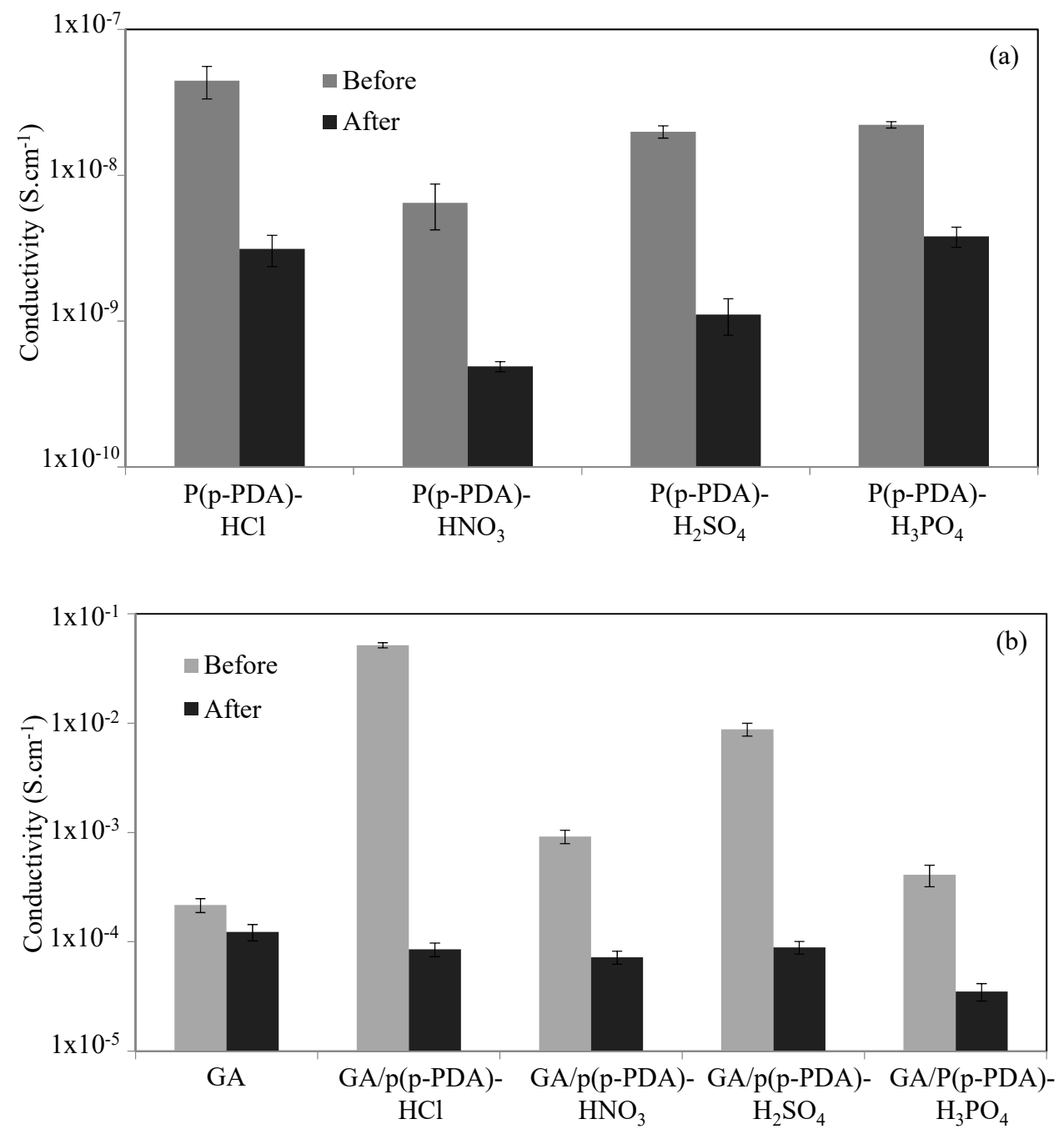

Figure 6. The conductivities of (a) p(p-PDA) polymers, and (b) GA/p (p-PDA) composites before and after $30 \mathrm{~min}$ of $\mathrm{CO}_{2}$ gas exposure.

Moreover, it was found that the conductivity of bare GA was calculated to be $2.17 \times 10^{-4} \pm 3.15 \times$ $10^{-5}$, and $1.23 \times 10^{-4} \pm 2.11 \times 10^{-5} \mathrm{~S} \cdot \mathrm{cm}^{-1}$, respectively, before and after $30 \mathrm{~min} \mathrm{CO}_{2}$ gas exposure, indicating poor sensitivity of bare $\mathrm{GA}$ to $\mathrm{CO}_{2}$ gas. On the other hand, approximately 600 -fold decrease in the conductivity of HCl-doped GA/p(p-PDA) composites from $5.16 \times 10^{-2} \pm 2.72 \times 10^{-3} \mathrm{~S} \cdot \mathrm{cm}^{-1}$ to $8.52 \times 10^{-5} \pm 1.21 \times 10^{-5} \mathrm{~S} \cdot \mathrm{cm}^{-1}$ after $30 \mathrm{~min}$ of $\mathrm{CO}_{2}$ gas exposure were attained.

Additionally, the conductivity of $\mathrm{H}_{2} \mathrm{SO}_{4}$-doped GA/p(p-PDA) composites appeared to show an approximately 100 -fold decrease from $8.78 \times 10^{-3} \pm 1.17 \times 10^{-3}$ to $8.91 \times 10^{-5} \pm 1.19 \times 10^{-5} \mathrm{~S} \cdot \mathrm{cm}^{-1}$ after 
30 min of $\mathrm{CO}_{2}$ gas exposure, whereas the changes in the conductivity of $\mathrm{HNO}_{3}{ }^{-}$, and $\mathrm{H}_{3} \mathrm{PO}_{4}$-doped $\mathrm{GA} / \mathrm{P}(\mathrm{p}-\mathrm{PDA})$ composites were far less than the others, with a 13- and 12-fold decrease, respectively, after 30 min exposure to $\mathrm{CO}_{2}$ gas.

The change in the conductivity of GA/p (p-PDA) composites in the course of $\mathrm{CO}_{2}$ exposure can be explained by diffusion of the gas within aerogel networks, which were the main reason that more conductivity reduction has been observed in GA/p(p-PDA) composites as compared to those of the free-standing $\mathrm{p}(\mathrm{p}-\mathrm{PDA})$ polymers. More specifically, the $\mathrm{CO}_{2}$ gas could not diffuse into the interiors of the bare $\mathrm{p}(\mathrm{p}-\mathrm{PDA})$ pellets, yet as a result of much higher surface area and macroporous structure of $\mathrm{GA} / \mathrm{p}(\mathrm{p}-\mathrm{PDA})$ composites along with the gas adsorption properties of the graphite and graphene oxide layers. Consequently, larger amounts of the $\mathrm{CO}_{2}$ gas were able to diffuse towards the porous network of the $\mathrm{HCl}$ - and $\mathrm{H}_{2} \mathrm{SO}_{4}$-doped $\mathrm{GA} / \mathrm{p}(\mathrm{p}$-PDA) composites and taped the pores much better. In addition, the positive charges, and unpaired electrons of in situ synthesized p(p-PDA) within GAs can easily interact with $\mathrm{CO}_{2}$ molecules, which have $\pi$-type $\mathrm{C}=\mathrm{O}$ binding ability and a lone pair of electrons [85].

The response of GA-based composites can be defined as a change in the conductivity in the presence of various amounts of $\mathrm{CO}_{2}$ molecules, and sensitivity can be defined as the ratio between the output signal (conductivity) per mole of the sensed molecule, $\mathrm{CO}_{2}$. Hence, the HCl-doped GA/p(p-PDA) composites exhibiting the greatest change in conductivity was studied for their sensitivity towards $\mathrm{CO}_{2}$ gas, and the change in the conductivity of $\mathrm{GA} / \mathrm{p}(\mathrm{p}-\mathrm{PDA})-\mathrm{HCl}$ composites was recorded at different exposure time scales, $0.5,1,5,10,20,30,45,60 \mathrm{~min}$ at $200 \mathrm{~mL} / \mathrm{min} \mathrm{CO}_{2}$ flow rate, and the corresponding $\mathrm{CO}_{2}$ sensitivity graph is presented in Figure 7a. The amounts of $\mathrm{CO}_{2}$ exposed to $\mathrm{GA} / \mathrm{p}(\mathrm{p}-\mathrm{PDA})-\mathrm{HCl}$ composites at $0.5,1,5,10,20,30,45$ and 60 min periods were calculated as $0.0045,0.009,0.045,0.09$, $0.18,0.27,0.40$, and 0.54 moles, respectively. It was observed that the change in conductivity of $\mathrm{GA} / \mathrm{p}$ (p-PDA)- $\mathrm{HCl}$ composites were increased with the increase in the time of $\mathrm{CO}_{2}$ gas exposure. Accordingly, 5.7-, 26.4-, 128-, 358-, 511-, 605-, 629-, and 633-fold conductivity decreases were recorded for GA/p(p-PDA)-HCl composites upon exposure to 198, 396, 1980, 3960, 7920, 11,980, 17,820, and $23,960 \mathrm{ppm} \mathrm{CO}$, respectively. The required concentration of $\mathrm{CO}_{2}$ for a healthy breath was stated to be less than $1000 \mathrm{ppm}$, and the concentration of $\mathrm{CO}_{2}$ in the atmosphere was $417 \mathrm{ppm}$ as of May 2020. According to the sensitivity graph of $\mathrm{HCl}$-doped GA/p(p-PDA) composites, $193.6 \mathrm{ppm}$ is enough to trigger a 5.7-fold decrease in the conductivity of GA/p (p-PDA)-HCl composites and gradually decreased e.g., a 26.4- and 128- fold decrease can be monitored at 397.2, and $1936 \mathrm{ppm} \mathrm{CO}_{2}$ concentration in only 1 and 5 min exposures, respectively. These results clearly indicate that $\mathrm{GA} / \mathrm{p}(\mathrm{p}-\mathrm{PDA})-\mathrm{HCl}$ composites can be used as a promising candidate for $\mathrm{CO}_{2}$ detection in various environmental applications including the detection of $\mathrm{CO}_{2}$ in the atmosphere. In here, the $\mathrm{GA} / \mathrm{p}(\mathrm{p}-\mathrm{PDA})-\mathrm{HCl}$ as $\mathrm{CO}_{2}$ sensor is based on the change in conductivity upon $\mathrm{CO}_{2}$ exposure in a concentration-dependent manner, so that the sensitivity can be calculated as conductivity changes (fold)mole of $\mathrm{CO}_{2}$. The sensitivity of GA/p(p-PDA)- $\mathrm{HCl}$ is calculated from the slope of Figure 7a, and it was observed that there was a 1288.7-fold of conductivity change(decrease)/mole of $\mathrm{CO}_{2}$ gas. 

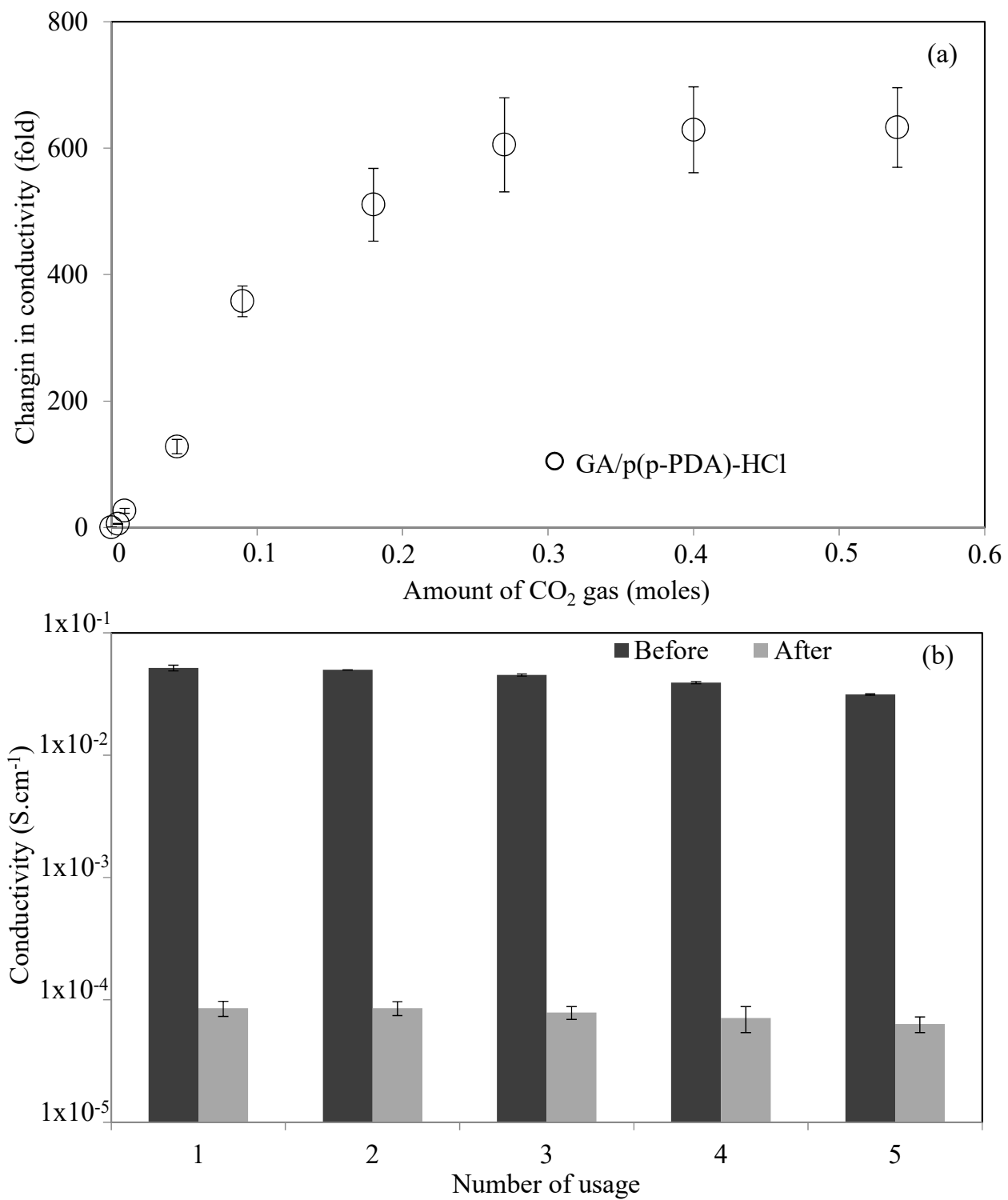

Figure 7. (a) The change in the conductivity of $\mathrm{GA} / \mathrm{p}(\mathrm{p}-\mathrm{PDA})-\mathrm{HCl}$ composites in the presence of the various amount of $\mathrm{CO}_{2}$ gas, and (b) reusability of $\mathrm{GA} / \mathrm{p}(\mathrm{p}-\mathrm{PDA})-\mathrm{HCl}$ composites.

Furthermore, the reusability of the prepared GA/p(p-PDA)-HCl composites were investigated for five successive (re)use and regeneration cycles, and the corresponding graph is illustrated in Figure $7 \mathrm{~b}$. It was observed that the conductivity of $\mathrm{GA} / \mathrm{p}(\mathrm{p}-\mathrm{PDA})-\mathrm{HCl}$ composites decreased from $5.16 \times 10^{-2} \pm 2.72 \times 10^{-3} \mathrm{~S} \cdot \mathrm{cm}^{-1}$ to $8.52 \times 10^{-5} \pm 1.21 \times 10^{-5} \mathrm{~S} \cdot \mathrm{cm}^{-1}$ after $30 \mathrm{~min}$ of $\mathrm{CO}_{2}$ gas exposure, and was recovered to $4.97 \times 10^{-2} \pm 1.13 \times 10^{-3} \mathrm{~S} \cdot \mathrm{cm}^{-1}$ after $2 \mathrm{~h}$ incubation at $60^{\circ} \mathrm{C}$. The conductivity of $\mathrm{GA} / \mathrm{p}(\mathrm{p}-\mathrm{PDA})-\mathrm{HCl}$ composites decreased from $4.97 \times 10^{-2} \pm 1.13 \times 10^{-3} \mathrm{~S} \cdot \mathrm{cm}^{-1}$ to $8.54 \times 10^{-5}$ $\pm 1.11 \times 10^{-5} \mathrm{~S} \cdot \mathrm{cm}^{-1}$ after the 2 nd cycle of $\mathrm{CO}_{2}$ gas exposure, and was recovered back to $4.51 \times$ $10^{-2} \pm 9.35 \times 10^{-4} \mathrm{~S} \cdot \mathrm{cm}^{-1}$ after the 2 nd cycle. Then, the conductivity of the composites decreased to $7.87 \times 10^{-5} \pm 9.84 \times 10^{-6} \mathrm{~S} \cdot \mathrm{cm}^{-1}$ after the $3 \mathrm{rd} \mathrm{CO}_{2}$ gas exposure, and it was again increased to $3.91 \times 10^{-2} \pm 8.11 \times 10^{-4} \mathrm{~S} \cdot \mathrm{cm}^{-1}$ after the 3 rd regeneration. The conductivity of GA/p(p-PDA)-HCl composites decreased from $3.91 \times 10^{-2} \pm 8.11 \times 10^{-4} \mathrm{~S} \cdot \mathrm{cm}^{-1}$ to $7.11 \times 10^{-5} \pm 1.71 \times 10^{-5} \mathrm{~S} \cdot \mathrm{cm}^{-1}$ in the 4th cycle of $\mathrm{CO}_{2}$ exposure, and then restored to $3.13 \times 10^{-2} \pm 4.01 \times 10^{-4} \mathrm{~S} \cdot \mathrm{cm}^{-1}$ after the 4th recovery. Finally, the conductivity decreased to $6.32 \times 10^{-5} \pm 9.23 \times 10^{-6} \mathrm{~S} \cdot \mathrm{cm}^{-1}$ after the 5 th $30 \mathrm{~min}$ of $\mathrm{CO}_{2}$ gas exposure. These findings clearly demonstrated that the GA/p(p-PDA)-HCl composites can be used in 
the detection of $\mathrm{CO}_{2}$ gas repeatedly after a $2 \mathrm{~h}$ of incubation at $60^{\circ} \mathrm{C}$, with almost full recovery to its initial conductivity measuring capability.

\section{Conclusions}

Herein, we demonstrated the potential usage of GAs as templates and sensory materials. Using GAs as templates in the in situ synthesis of conductive $\mathrm{p}(\mathrm{p}-\mathrm{PDA})$ polymers clearly reveals the the versatility of these materials. The acid types, $\mathrm{HCl}, \mathrm{HNO}_{3}, \mathrm{H}_{2} \mathrm{SO}_{4}$, and $\mathrm{H}_{3} \mathrm{PO}_{4}$ used in doping of $\mathrm{p}$ (p-PDA) polymers were found to have a considerable influence on the electrical conductivity of both p(p-PDA) polymers and their corresponding GA-based composites. GA/p(p-PDA) composites achieved higher electrical conductivities than both their bare $\mathrm{p}(\mathrm{p}-\mathrm{PDA})$ polymers and bare GAs. The in situ synthesis of $\mathrm{GA} / \mathrm{p}$ (p-PDA)-HCl composites gave rise to a 250 -fold increase in the conductivity of bare GAs from $2.17 \times 10^{-4} \pm 3.15 \times 10^{-5} \mathrm{~S} \cdot \mathrm{cm}^{-1}$ to $5.16 \times 10^{-2} \pm 2.72 \times 10^{-3} \mathrm{~S} \cdot \mathrm{cm}^{-1}$. Moreover, GA/P(p-PDA)-HCl composites were revealed to show the best response to $\mathrm{CO}_{2}$ gas amongst other acid-doped composites, with an approximately 600 -fold conductivity decrease. Owing to the well-known properties of graphene oxides and GAs to absorb gases, and the response of in situ prepared $\mathrm{p}(\mathrm{p}-\mathrm{PDA})$ conductive polymer, $\mathrm{GA} / \mathrm{p}$ (p-PDA) composites were shown to be a sensor for $\mathrm{CO}_{2}$ gas with the capability of measuring $\mathrm{CO}_{2}$ levels in the atmosphere, which are well within its sensitivity level. Although the gravimetric amount of in situ synthesized $\mathrm{p}(\mathrm{p}-\mathrm{PDA})$ polymers with $\mathrm{HCl}$ doping in $\mathrm{GA} / \mathrm{p}(\mathrm{p}-\mathrm{PDA})$ composites is less than that of $\mathrm{H}_{2} \mathrm{SO}_{4}$ - and $\mathrm{H}_{3} \mathrm{PO}_{4}$-doped $\mathrm{GA} / \mathrm{p}$ (p-PDA) composites, better electrical conductivity, as well as better $\mathrm{CO}_{2}$ response of this material, affords better outcomes in terms of real applications. Furthermore, $\mathrm{GA} / \mathrm{p}$ (p-PDA)-HCl composites exhibited a 5.7-fold conductivity decrease even at $193.6 \mathrm{ppm} \mathrm{CO}_{2}$ gas concentration in only $30 \mathrm{sec}$, and a 26.4-fold decrease in $1 \mathrm{~min}$ at $397.2 \mathrm{ppm} \mathrm{CO}_{2}$ concentration, along with the sensitivity of 1288.7 fold conductivity decrease $/ \mathrm{mole}$ of $\mathrm{CO}_{2}$ gas. Since these concentrations are less than the half of those reported as dangerous, $\mathrm{GA} / \mathrm{p}(\mathrm{p}-\mathrm{PDA})-\mathrm{HCl}$ composites hold remarkable potential in the determination $\mathrm{CO}_{2}$ as a sensor in many industrial effluents and mining applications, and so on.

Overall, it is apparent that GA-based materials offer a lot of potential, as they are not restricted to $\mathrm{CO}_{2}$ sensors and detectors in chimneys of factories, dwellings, and lab gadgets such as $\mathrm{CO}_{2}$ incubators, etc., to determine the level of emitted/generated or released $\mathrm{CO}_{2}$, but they may also be useful to track accumulated levels of $\mathrm{CO}_{2}$ in different milieus, including climate chambers and indoor living environments, and so on.

Supplementary Materials: The following are available online at http://www.mdpi.com/2072-666X/11/7/626/s1, Figure S1: The FT-IR spectrum of bare p(p-PDA) polymers doped with various types of acids.

Author Contributions: Formal analysis, Investigation, Methodology, Writing-original draft: S.D.; Formal analysis, Investigation, Methodology, Writing—original draft: M.C.; Conceptualization, Funding acquisition, Formal analysis, Visualization, Methodology, Resources, Supervision, Writing-review \& editing: N.S. All authors have read and agreed to the published version of the manuscript.

Funding: This research received no external funding.

Acknowledgments: Authors are grateful to Erk Inger for great discussion regarding $\mathrm{CO}_{2}$ in the atmosphere.

Conflicts of Interest: The authors declare no conflict of interest.

\section{References}

1. Nasir, S.; Hussein, M.Z.; Zainal, Z.; Yusof, N.A. Carbon-based nanomaterials/allotropes: A glimpse of their synthesis, properties and some applications. Materials 2018, 11, 295. [CrossRef]

2. Dos Santos, M.C.; Maynart, M.C.; Aveiro, L.R.; da Paz, E.C.; dos Santos Pinheiro, V. Carbon-Based Materials: Recent Advances, Challenges, and Perspectives; Elsevier Ltd.: Amsterdam, The Netherlands, 2017; ISBN 9780128035818.

3. Patel, K.D.; Singh, R.K.; Kim, H.W. Carbon-based nanomaterials as an emerging platform for theranostics. Mater. Horiz. 2019, 6, 434-469. [CrossRef] 
4. Tiwari, S.K.; Sahoo, S.; Wang, N.; Huczko, A. Graphene research and their outputs: Status and prospect. J. Sci. Adv. Mater. Devices 2020, 5, 10-29. [CrossRef]

5. Geim, A.K.; Novoselov, K.S. The rise of graphene. Nat. Mater. 2007, 6, 183-191. [CrossRef]

6. Kong, W.; Kum, H.; Bae, S.H.; Shim, J.; Kim, H.; Kong, L.; Meng, Y.; Wang, K.; Kim, C.; Kim, J. Path towards graphene commercialization from lab to market. Nat. Nanotechnol. 2019, 14, 927-938. [CrossRef]

7. Zhu, Y.; Murali, S.; Cai, W.; Li, X.; Suk, J.W.; Potts, J.R.; Ruoff, R.S. Graphene and graphene oxide: Synthesis, properties, and applications. Adv. Mater. 2010, 22, 3906-3924. [CrossRef]

8. Yu, X.; Cheng, H.; Zhang, M.; Zhao, Y.; Qu, L.; Shi, G. Graphene-based smart materials. Nat. Rev. Mater. 2017, 2, 1-14. [CrossRef]

9. Ju, S.; Liang, B.; Wang, J.Z.; Shi, Y.; Li, S.L. Graphene/silicon Schottky solar cells: Technical strategies for performance optimization. Opt. Commun. 2018, 428, 258-268. [CrossRef]

10. Chen, S.; Li, H.; Zhao, K.; Wu, D. Preparation of graphene films bridged with Ag nanowires and its application in heterojunction solar cells. Sol. Energy 2020, 198, 167-174. [CrossRef]

11. Zhao, G.; Feng, C.; Cheng, H.; Li, Y.; Wang, Z.S. In situ thermal conversion of graphene oxide films to reduced graphene oxide films for efficient dye-sensitized solar cells. Mater. Res. Bull. 2019, 120,1-7. [CrossRef]

12. Singh, D.; Quraishi, M.A.; Ansari, K.R.; Saleh, A. Graphene and graphene oxide as new class of materials for corrosion control and protection: Present status and future scenario. Prog. Org. Coat. 2020, 147. [CrossRef]

13. Huang, X.; Zeng, Z.; Fan, Z.; Liu, J.; Zhang, H. Graphene-based electrodes. Adv. Mater. 2012, 24, $5979-6004$. [CrossRef] [PubMed]

14. Woo, Y.S. Transparent conductive electrodes based on graphene-related materials. Micromachines 2018, 10, 13. [CrossRef] [PubMed]

15. Novoselov, K.S.; Fal'Ko, V.I.; Colombo, L.; Gellert, P.R.; Schwab, M.G.; Kim, K. A roadmap for graphene. Nature 2012, 490, 192-200. [CrossRef]

16. Bai, Y.; Xu, T.; Zhang, X. Graphene-based biosensors for detection of biomarkers. Micromachines 2020, 11, 60. [CrossRef]

17. Yoon, H.; Nah, J.; Kim, H.; Ko, S.; Sharifuzzaman, M.; Barman, S.C.; Xuan, X.; Kim, J.; Park, J.Y. A chemically modified laser-induced porous graphene based flexible and ultrasensitive electrochemical biosensor for sweat glucose detection. Sens. Actuators B Chem. 2020, 311, 127866. [CrossRef]

18. Huang, Y.; Dong, X.; Liu, Y.; Li, L.J.; Chen, P. Graphene-based biosensors for detection of bacteria and their metabolic activities. J. Mater. Chem. 2011, 21, 12358-12362. [CrossRef]

19. Li, N.; Chen, Z.; Ren, W.; Li, F.; Cheng, H.M. Flexible graphene-based lithium ion batteries with ultrafast charge and discharge rates. Proc. Natl. Acad. Sci. USA 2012, 109, 17360-17365. [CrossRef]

20. Goenka, S.; Sant, V.; Sant, S. Graphene-based nanomaterials for drug delivery and tissue engineering. J. Control. Release 2014, 173, 75-88. [CrossRef]

21. Tadyszak, K.; Wychowaniec, J.K.; Litowczenko, J. Biomedical applications of graphene-based structures. Nanomaterials 2018, 8, 944. [CrossRef]

22. Kamran, U.; Heo, Y.J.; Lee, J.W.; Park, S.J. Functionalized carbon materials for electronic devices: A review. Micromachines 2019, 10, 234. [CrossRef] [PubMed]

23. Huang, Y.; Huang, Z.; Zhong, Z.; Yang, X.; Hong, Q.; Wang, H.; Huang, S.; Gao, N.; Chen, X.; Cai, D.; et al. Highly transparent light emitting diodes on graphene encapsulated $\mathrm{Cu}$ nanowires network. Sci. Rep. 2018, 8 , 1-11. [CrossRef]

24. Jiang, G.; Tian, H.; Wang, X.F.; Hirtz, T.; Wu, F.; Qiao, Y.C.; Gou, G.Y.; Wei, Y.H.; Yang, J.M.; Yang, S.; et al. An efficient flexible graphene-based light-emitting device. Nanoscale Adv. 2019, 1, 4745-4754. [CrossRef]

25. Kim, U.; Kang, J.; Lee, C.; Kwon, H.Y.; Hwang, S.; Moon, H.; Koo, J.C.; Nam, J.-D.; Hong, B.H.; Choi, J.B.; et al. A transparent and stretchable graphene-based actuator for tactile display. Nanotechnology 2013, 24. [CrossRef] [PubMed]

26. Lei, W.; Li, C.; Cole, M.T.; Qu, K.; Ding, S.; Zhang, Y.; Warner, J.H.; Zhang, X.; Wang, B.; Milne, W.I. A graphene-based large area surface-conduction electron emission display. Carbon 2013, 56, 255-263. [CrossRef]

27. Anagnostopoulos, G.; Pappas, P.N.; Li, Z.; Kinloch, I.A.; Young, R.J.; Novoselov, K.S.; Lu, C.Y.; Pugno, N.; Parthenios, J.; Galiotis, C.; et al. Mechanical stability of flexible graphene-based displays. ACS Appl. Mater. Interfaces 2016, 8, 22605-22614. [CrossRef] [PubMed] 
28. Wasalathilake, K.C.; Li, H.; Xu, L.; Yan, C. Recent advances in graphene based materials as anode materials in sodium-ion batteries. J. Energy Chem. 2020, 42, 91-107. [CrossRef]

29. Fang, R.; Zhao, S.; Chen, K.; Wang, D.-W.; Li, F. Binary graphene-based cathode structure for high-performance lithium-sulfur batteries. J. Phys. Energy 2020, 2, 015003. [CrossRef]

30. El-Kady, M.F.; Shao, Y.; Kaner, R.B. Graphene for batteries, supercapacitors and beyond. Nat. Rev. Mater. 2016, 1, 1-14. [CrossRef]

31. Liu, C.; Yu, Z.; Neff, D.; Zhamu, A.; Jang, B.Z. Graphene-based supercapacitor with an ultrahigh energy density. Nano Lett. 2010, 10, 4863-4868. [CrossRef]

32. Tang, G.; Jiang, Z.G.; Li, X.; Zhang, H.B.; Dasari, A.; Yu, Z.Z. Three dimensional graphene aerogels and their electrically conductive composites. Carbon 2014, 77, 592-599. [CrossRef]

33. Park, S.; Ruoff, R.S. Chemical methods for the production of graphenes. Nat. Nanotechnol. 2009, 4, $217-224$. [CrossRef] [PubMed]

34. Sahiner, N. Conductive polymer containing graphene aerogel composites as sensor for $\mathrm{CO}_{2}$. Polym. Compos. 2019, 40, E1208-E1218. [CrossRef]

35. Korkmaz, S.; Kariper, A. Graphene and graphene oxide based aerogels: Synthesis, characteristics and supercapacitor applications. J. Energy Storage 2020, 27. [CrossRef]

36. Stankovich, S.; Dikin, D.A.; Dommett, G.H.B.; Kohlhaas, K.M.; Zimney, E.J.; Stach, E.A.; Piner, R.D.; Nguyen, S.B.T.; Ruoff, R.S. Graphene-based composite materials. Nature 2006, 442, 282-286. [CrossRef]

37. Wu, X.; Xing, Y.; Pierce, D.; Zhao, J.X. One-pot synthesis of reduced graphene oxide/metal (oxide) composites. ACS Appl. Mater. Interfaces 2017, 9, 37962-37971. [CrossRef]

38. Feng, H.; Li, Y.; Li, J. Strong reduced graphene oxide-polymer composites: Hydrogels and wires. RSC Adv. 2012, 2, 6988-6993. [CrossRef]

39. Sahiner, N.; Demirci, S. The use of graphene oxide-embedded superporous poly(2-hydroxyethylmethacrylate) cryogels for $\mathrm{p}$ (aniline) conductive polymer synthesis and their use in sensor applications. Mater. Des. 2017, 120, 47-55. [CrossRef]

40. Alwin, S.; Sahaya Shajan, X. Aerogels: Promising nanostructured materials for energy conversion and storage applications. Mater. Renew. Sustain. Energy 2020, 9, 1-27. [CrossRef]

41. Yang, L.; Li, Y.; Zhang, Y.; Fan, D.; Pang, X.; Wei, Q.; Du, B. 3D nanostructured palladium-functionalized graphene-aerogel-supported $\mathrm{Fe} 3 \mathrm{O} 4$ for enhanced $\mathrm{Ru}(\mathrm{bpy}) 32+-$ based electrochemiluminescent immunosensing of prostate specific antigen. ACS Appl. Mater. Interfaces 2017, 9, 35260-35267. [CrossRef]

42. Zhao, Y.; Xie, X.; Zhang, J.; Liu, H.; Ahn, H.J.; Sun, K.; Wang, G. MoS2 nanosheets supported on 3D graphene aerogel as a highly efficient catalyst for Hydrogen evolution. Chem. Eur. J. 2015, 21, 15908-15913. [CrossRef] [PubMed]

43. Luo, B.; Liu, S.; Zhi, L. Chemical approaches toward graphene-based nanomaterials and their applications in energy-related areas. Small 2012, 8, 630-646. [CrossRef] [PubMed]

44. Rodríguez-Mata, V.; González-Domínguez, J.M.; Benito, A.M.; Maser, W.K.; García-Bordejé, E. Reduced graphene oxide aerogels with controlled continuous microchannels for environmental remediation. ACS Appl. Nano Mater. 2019, 2, 1210-1222. [CrossRef]

45. Jiang, Y.; Chowdhury, S.; Balasubramanian, R. Nitrogen and sulfur codoped graphene aerogels as absorbents and visible light-active photocatalysts for environmental remediation applications. Environ. Pollut. 2019, 251, 344-353. [CrossRef] [PubMed]

46. Wang, B.; Wang, G.; Lv, Z.; Wang, H. In situ synthesis of hierarchical $\mathrm{CoFe}_{2} \mathrm{O}_{4}$ nanoclusters/graphene aerogels and their high performance for lithium-ion batteries. Phys. Chem. Chem. Phys. 2015, 17, 27109-27117. [CrossRef]

47. Qiu, B.; Xing, M.; Zhang, J. Mesoporous $\mathrm{TiO}_{2}$ nanocrystals grown in situ on graphene aerogels for high photocatalysis and lithium-ion batteries. J. Am. Chem. Soc. 2014, 136, 5852-5855. [CrossRef]

48. Xu, D.; Liu, J.; Chen, P.; Yu, Q.; Wang, J.; Yang, S.; Guo, X. In situ growth and pyrolysis synthesis of super-hydrophobic graphene aerogels embedded with ultrafine $\beta$-Co nanocrystals for microwave absorption. J. Mater. Chem. C 2019, 7, 3869-3880. [CrossRef]

49. Juanjuan, Z.; Ruiyi, L.; Zaijun, L.; Junkang, L.; Zhiguo, G.; Guangli, W. Synthesis of nitrogen-doped activated graphene aerogel/gold nanoparticles and its application for electrochemical detection of hydroquinone and o-dihydroxybenzene. Nanoscale 2014, 6, 5458-5466. [CrossRef] 
50. Ye, Y.; Yin, D.; Wang, B.; Zhang, Q. Synthesis of three-dimensional Fe3O4/graphene aerogels for the removal of arsenic ions from water. J. Nanomater. 2015, 2015. [CrossRef]

51. Zhu, C.; Xu, J.; Song, S.; Wang, J.; Li, Y.; Liu, R.; Shen, Y. $\mathrm{TiO}_{2}$ quantum dots loaded sulfonated graphene aerogel for effective adsorption-photocatalysis of PFOA. Sci. Total Environ. 2020, 698, 134275. [CrossRef]

52. Wang, Y.; Yao, B.; Chen, H.; Wang, H.; Li, C.; Yang, Z. Preparation of anisotropic conductive graphene aerogel/polydimethylsiloxane composites as LEGO ${ }^{\circledR}$ modulars. Eur. Polym. J. 2019, 112, 487-492. [CrossRef]

53. Lv, P. Highly compressible graphene/polypyrrole aerogel for superelastic pseudocapacitors. Fuller. Nanotub. Carbon Nanostruct. 2018, 26, 23-29. [CrossRef]

54. Le, T.-H.; Kim, Y.; Yoon, H. Electrical and electrochemical properties of conducting polymers. Polymers 2017, 9, 150. [CrossRef]

55. Sahiner, N.; Demirci, S. The use of $\mathrm{p}(4-\mathrm{VP})$ cryogel as template for in situ preparation of $\mathrm{p}(\mathrm{An}), \mathrm{p}(\mathrm{Py})$, and $\mathrm{p}(\mathrm{Th})$ conductive polymer and their potential sensor applications. Synth. Met. 2017, 227, 11-20. [CrossRef]

56. Sahiner, N.; Demirci, S. The use of covalent organic frameworks as template for conductive polymer synthesis and their sensor applications. J. Porous Mater. 2019, 26, 481-492. [CrossRef]

57. Hu, H.; Zhao, Z.; Zhang, R.; Bin, Y.; Qiu, J. Polymer casting of ultralight graphene aerogels for the production of conductive nanocomposites with low filling content. J. Mater. Chem. A 2014, 2, 3756-3760. [CrossRef]

58. Hu, H.; Zhao, Z.; Wan, W.; Gogotsi, Y.; Qiu, J. Polymer/graphene hybrid aerogel with high compressibility, conductivity, and "sticky" superhydrophobicity. ACS Appl. Mater. Interfaces 2014, 6, 3242-3249. [CrossRef]

59. Jia, X.; Roels, J.; Boets, R.; Roelkens, G. On-chip non-dispersive infrared $\mathrm{CO}_{2}$ sensor based on an integrating cylinder. Sensors 2019, 19, 4260. [CrossRef]

60. Zhou, S.; Xu, H.; Yuan, Q.; Shen, H.; Zhu, X.; Liu, Y.; Gan, W. N-doped ordered mesoporous carbon originated from a green biological dye for electrochemical sensing and high-pressure $\mathrm{CO}_{2}$ storage. ACS Appl. Mater. Interfaces 2016, 8, 918-926. [CrossRef]

61. Wu, C.W.; Chiang, C.C. Sandwiched long-perion fiber grating fabricated by MEMS process for $\mathrm{CO}_{2}$ gas detection. Micromachines 2016, 7, 35. [CrossRef]

62. Barauskas, D.; Pelenis, D.; Vanagas, G.; Virzonis, D.; Baltrusaitis, J. Methylated poly(ethylene)imine modified capasicitive micromachined ultrasonic transducefor measurements of $\mathrm{CO}_{2}$ and $\mathrm{SO}_{2}$ in tehir mixture. Sensors 2019, 19, 3236. [CrossRef] [PubMed]

63. Tanvir, N.B.; Yurchenko, O.; Laubender, E.; Urban, G. Investigation of low temperature effects on work function based $\mathrm{CO}_{2}$ gas sensing of nanoparticulate $\mathrm{CuO}$ films. Sensor. Actuators B Chem. 2017, 247, 968-974. [CrossRef]

64. Willa, C.; Yuan, J.; Niederberger, M.; Kozlej, D. When nanoparticles meet Poly(Ionic liquid)s: Chemoresistive $\mathrm{CO}_{2}$ sensing at room temperature. Adv. Funct. Mater. 2015, 25, 2537-2542. [CrossRef]

65. Endres, H.E.; Hartinger, R.; Schwaiger, M.; Gmelch, G.; Roth, M. A capacitive $\mathrm{CO}_{2}$ sensor system with suppression of the humidity interfaces. Sens. Actuators B Chem. 1999, 57, 83-87. [CrossRef]

66. Singh, E.; Meyyappan, M.; Nalwa, H.S. Flexible graphene-based wearable gas and chemical sensors. ACS Appl. Mater. Interfaces 2017, 9, 34544-34586. [CrossRef]

67. Zhang, X.; Sui, Z.; Xu, B.; Yue, S.; Luo, Y.; Zhan, W.; Liu, B. Mechanically strong and highly conductive graphene aerogel and its use as electrodes for electrochemical power sources. J. Mater. Chem. 2011, 21, 6494-6497. [CrossRef]

68. Hummers, W.S.; Offeman, R.E. Preparation of graphitic oxide. J. Am. Chem. Soc. 1958, 80, 1339. [CrossRef]

69. Cataldo, F. On the polymerization of P-phenylenediamine. Eur. Polym. J. 1996, 32, 43-50. [CrossRef]

70. Baro, M.; Jaidev; Ramaprabhu, S. Conductive and nitrogen-enriched porous carbon nanostructure derived from poly (para-phenylenediamine) for energy conversion and storage applications. Appl. Surf. Sci. 2020, 503, 144069. [CrossRef]

71. Durgaryan, A.A.; Arakelyan, R.A.; Durgaryan, N.A. Oxidative polymerization of p-phenylenediamine. Russ. J. Gen. Chem. 2014, 84, 1095-1100. [CrossRef]

72. Sayyah, S.M.; Khaliel, A.B.; Aboud, A.A.; Mohamed, S.M. Chemical polymerization kinetics of poly-o-phenylenediamine and characterization of the obtained polymer in aqueous hydrochloric acid solution using $\mathrm{K}_{2} \mathrm{Cr}_{2} \mathrm{O}_{7}$ as oxidizing agent. Int. J. Polym. Sci. 2014, 2014, 1-16. [CrossRef]

73. Kong, Y.; Jiang, G.; Fan, M.; Shen, X.; Cui, S.; Russell, A.G. A new aerogel based $\mathrm{CO}_{2}$ adsorbent developed using a simple sol-gel method along with supercritical drying. Chem. Commun. 2014, 50, 12158. [CrossRef] [PubMed] 
74. Guo, J.; Nguyen, B.N.; Li, L.; Meador, M.A.B.; Scheiman, D.A.; Cakmak, M. Clay reinforced polyimide/silica hybrid aerogel. J. Mater. Chem. A. 2013, 1,7211-7221. [CrossRef]

75. Li, T.; Yuan, C.; Zhao, Y.; Chen, Q.; Wei, M.; Wang, Y. Synthesis, characterization, and properties of aniline-p-phenylenediamine copolymers. High Perform. Polym. 2013, 25, 348-353. [CrossRef]

76. Ren, L.; Hui, K.S.; Hui, K.N. Self-assembled free-standing three-dimensional nickel nanoparticle/graphene aerogel for direct ethanol fuel cells. J. Mater. Chem. A 2013, 1, 5689-5694. [CrossRef]

77. Guo, H.-L.; Wang, X.-F.; Qian, Q.-Y.; Wang, F.-B.; Xia, X.-H. A Green approach to the synthesis of graphene nanosheets. ACS Nano 2009, 3, 2653-2659. [CrossRef]

78. Li, R.; Chen, C.; Li, J.; Xu, L.; Xiao, G.; Yan, D. A facile approach to superhydrophobic and superoleophilic graphene/polymer aerogels. J. Mater. Chem. A 2014, 2, 3057. [CrossRef]

79. Wu, J.; Tang, Q.; Li, Q.; Lin, J. Self-assembly growth of orionted polyaniline arrays: A morphology and structure study. Polymer 2008, 49, 5262-5267. [CrossRef]

80. Askeland, D.R.; Fulay, P.P.; Wright, W.J. The Science and Engineering of Materials, 6th ed.; Cengage Learning: Boston, MA, USA, 2011.

81. Taherian, R. The theory of electrical conductivity. In Electrical Conductivity in Polymer-Based Composites, 1st ed.; Taherian, R., Kausar, A., Eds.; William Andrew: New York, NY, USA, 2018; pp. 1-18.

82. Erdmann, C.A.; Apte, M.G. Mucous membrane and lower respiratory building related symptoms in relation to indoor carbon dioxide concentrations in the 100-building BASE dataset. Indoor Air. Suppl. 2004, 14, 127-134. [CrossRef]

83. Lin, Y.; Fan, Z. Compositing strategies to enhance the performance of chemiresistive $\mathrm{CO}_{2}$ gas sensors. Mater. Sci. Semicond. Process. 2020, 107, 104820. [CrossRef]

84. Demirci, S.; Sahiner, N. The use of conductive polymers embedded macro porous pei and ionic liquid form of pei cryogels for potential conductometric sensor application to $\mathrm{CO}_{2}$. J. Compos. Sci. 2020, 4, 27. [CrossRef]

85. Waghuley, S.A.; Yenorkar, S.M.; Yawale, S.S.; Yawale, S.P. Application of chemically synthesized conducting polymer-polypyrrole as a carbon dioxide gas sensor. Sens. Actuators B Chem. 2008, 128, 366-373. [CrossRef]

(C) 2020 by the authors. Licensee MDPI, Basel, Switzerland. This article is an open access article distributed under the terms and conditions of the Creative Commons Attribution (CC BY) license (http://creativecommons.org/licenses/by/4.0/). 